\title{
Model and Assessment of the Contribution of Dredged Material Disposal to Sea-Surface Contamination in Puget Sound
}
J. T. Hardy
C. E. Cowan

February 1986

Prepared for

the U.S. Army Corps of Engineers

Seattle District

under a Related Services Agreement

with the U.S. Department of Energy

Contract DE-AC06-76RLO 1830

Pacific Northwest Laboratory

Operated for the U.S. Department of Energy

by Battelle Memorial Institute 


\title{
DISCLAIMER
}

This report was prepared as an account of work sponsored by an agency of the United States Government. Neither the United States Government nor any agency thereof, nor any of their employees, makes any warranty, express or implied, or assumes any legal liability or responsibility for the accuracy, completeness, or usefulness of any information, apparatus, product, or process disclosed, or represents that its use would not infringe privately owned rights. Reference herein to any specific commercial product, process, or service by trade name, trademark, manufacturer, or otherwise, does not necessarily constitute or imply its endorsement, recommendation, or favoring by the United States Government or any agency thereof. The views and opinions of authors expressed herein do not necessarily state or reflect those of the United States Government or any agency thereof.

\author{
PACIFIC NORTHWEST LABORATORY \\ operated by \\ BATTELLE \\ for the \\ UNITED STATES DEPARTMENT OF ENERGY \\ under Contract DE-AC06-76RLO 1830
}

\begin{tabular}{|c|c|}
\hline \multicolumn{2}{|c|}{ Printed in the United States of America } \\
\hline \multicolumn{2}{|c|}{ Available from } \\
\hline \multirow{2}{*}{\multicolumn{2}{|c|}{$\begin{array}{l}\text { National Technical Information Service } \\
\text { United States Department of Commerce }\end{array}$}} \\
\hline & \\
\hline \multicolumn{2}{|c|}{$\begin{array}{l}\text { United States Department of Commerce } \\
52285 \text { Port Royal Road }\end{array}$} \\
\hline \multicolumn{2}{|c|}{ Springfield, Virginia 22161} \\
\hline \multirow{2}{*}{\multicolumn{2}{|c|}{$\begin{array}{l}\text { NTIS Price Codes } \\
\text { Microfiche A01 }\end{array}$}} \\
\hline & \\
\hline \multicolumn{2}{|c|}{ Printed Copy } \\
\hline & Price \\
\hline Pages & Codes \\
\hline $001-025$ & $\mathrm{~A} 02$ \\
\hline $026-050$ & $\mathrm{~A} 03$ \\
\hline $051-075$ & $\mathrm{~A} 04$ \\
\hline $076-100$ & A05 \\
\hline $101-125$ & A06 \\
\hline $126-150$ & A07 \\
\hline $151-175$ & $A 08$ \\
\hline $176-200$ & $\wedge 09$ \\
\hline $201-225$ & A010 \\
\hline $226-250$ & A011 \\
\hline $251-275$ & $A 012$ \\
\hline $276-300$ & $A 013$ \\
\hline
\end{tabular}


MODEL AND ASSESSMENT OF THE CONTRIBUTION

OF DREDGED MATERIAL DISPOSAL TO SEA-SURFACE CONTAMINATION IN PUGET SOUND

\section{J. T. Hardy}

Marine Research Laboratory

Sequim, Washington

C. E. Cowan

Pacific Northwest Laboratory

February 1986

Prepared for

the U.S. Army Corps of Engineers

Seattle District

under a Related Services Agreement

with the U.S. Department of Energy

Contract DE-ACO6-76RLO 1830

Pacific Northwest Laboratory

Richland, Washington 99352 
.

, 
Hydrophobic or floatable materials released to the water column during dredge disposal operations may accurnulate in high concentrations on the water surface. If such surface accumulations occur, they could impact the reproduction of fish and shellfish with neustonic (floating) eggs or larvae. Also, floatable surface contaminants could deposit on nearby beaches. In order to examine the potential impacts of such processes, an interactive computer (IBM PC) model was developed. The FORTRAN model, allows input of contaminant concentrations on the dredge material, the surface area of the disposal site, the floatable fraction of the contaminated material, and the baseine concentrations of contaminants present in the sea-surface microlayer. The model then computes the resultant concentrations of each contaminant in the microlayer and the potential impact on floating fish eggs. The utility of the model would be greatly improved by empirical data, not yet available, on the vertical upward and lateral movement of contaminants during dredge material disposal. 


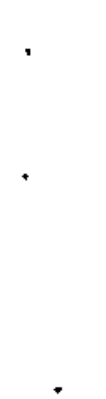

• 


\section{CONTENTS}

SUMMARY

INTRODUCTION

CONCLUSIONS AND RECOMMENDATIONS

MODEL

ASSUMPTIONS AND LIMITATIONS

SAMPLE SCENARIOS

\section{5}

RELATIONSHIP TO WATER QUALITY CRITERIA $\ldots \ldots \ldots \ldots \ldots \ldots \ldots \ldots \ldots \ldots \ldots \ldots$

REFERENCES $\ldots \ldots \ldots \ldots \ldots \ldots \ldots \ldots \ldots \ldots \ldots \ldots \ldots \ldots \ldots \ldots \ldots \ldots \ldots \ldots \ldots$

APPENDIX A - FLOW CHART OF MODEL $\ldots \ldots \ldots \ldots \ldots \ldots \ldots \ldots \ldots \ldots \ldots \ldots \ldots \ldots \ldots$

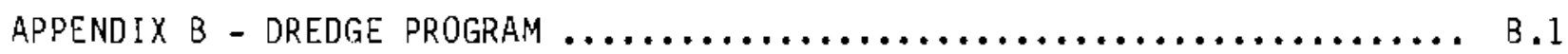

APPENDIX $\mathrm{C}$ - SAMPLE DREDGE DISPOSAL SCENARIOS $\ldots \ldots \ldots \ldots \ldots \ldots \ldots \ldots \ldots \ldots$ 


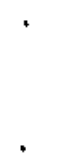




\section{INTRODUCTION}

The sea-surface microlayer (SSM) is a vital biological habitat (Hardy 1982). Many fish and shelifish, including cod, sole, flounder, hake, anchovy, crab, and lobster have egg or larval stages that develop in this upper layer. Contaminants from atmospheric deposition, urban runoff, wastewater outfalls, industrial point sources, and ocean dumping enter coastal waters and partition. A large portion of these contaminants associate with suspended particles and deposit in the bottom sediments. However, contaminants that have low water solubility or that associate with floatable particles concentrate at the airwater interface. Consequently, high concentrations of toxic PAHs, PCBs, and metals have been found in the surface microlayer at some sites in Puget Sound (Hardy et al. 1986). At present, the spatial distribution of this SSM contamination remains unknown. Also, the relative contribution that dredged material disposal may make to SSM contamination remains to be assessed. As part of the Puget Sound Dredged Disposal Analysis program of the Seattle District Corps of Engineers, this project was undertaken to examine the potential of dredged material contaminants to accumulate in harmful concentrations at the sea surface. This study was performed to 1) develop a model that will allow estimation of the increase in, and the resulting concentration of, a series of poliutants in the SSM caused by dredging activities and 2) to estimate the resulting impact of SSM contamination in terms of its toxicity to fish eggs that float on the water surface during the spawning season. 


\section{CONCLUSIONS AND RECOMMENDATIONS}

Significant SSM contamination and toxicity already exists in Elliott Bay. Dredge disposal could only significantly add to this contamination and toxicity within the disposal area if the floatable fraction exceeds $1 \times 10^{-10}$ to $10^{-9}$ and most of the surface contamination remains in the microlayer for some time. Also, additional contamination from floatables could, through horizontal transport, add to the load of contamination deposited on nearby beaches. However, several gaps in information seriously impair the usefulness of this model. These include lack of information on the floatable and bioavailable fraction of the dredged material and the "footprint" or area of the water surface likely to be impacted from the disposal.

We recommend that laboratory and field experiments be conducted to

- Determine the floatable fraction of dredged material under a variety of different mixing and disposal regimes.

- Collect and chemically analyze sea-surface microlayer contaminant concentrations during a typical dredge disposal operation.

- Evaluate the toxicity of the floatable fraction of dredged material to neustonic (floating) eggs and larvae. 
MODEL

The model we have developed is written in FORTRAN to run on an IBM PC. The model is interactive and requests all the necessary input data from the user. Results are displayed and can be printed on hard copy. The data from a given simulation can be stored, if desired, on a file specified by the user. The user has the option of changing one or more of the parameters for the simulation including the mass of material dumped, the floatabiltiy fraction, the concentration of contaminants in the dredged material and that initially in the microlayer. The program then computes the final concentrations of contaminants in the SSM and the resulting expected fish egg mortality.

The structure for the model is presented in a series of flow charts (see Appendix A), and the program is listed in Appendix B. Basically, the model uses data on the characteristics of the dredged material to determine how much of the contaminated material accumulates in the SSM. Input variables are concentrations of up to 10 contaminants in the sediment, total mass of dredeged material to be dumped at the site, area of the disposal site, and a measure of the fraction of the material that is floatable. Floatability is, of course, a function of the particle size and density, and is affected by the presence of organic coatings. This is probably the largest unknown input variable at pres. ent. From these parameters the total mass of each contaminant added to the microlayer is computed. Other input variables are the initial (baseline) concentration of each contaminant in the microlayer and the water surface area of the disposal site that is estimated to be affected. When the initial (baseline) concentrations of contaminants are entered as 0 , the computed final concentrations and toxicity represent those resulting solely from the dredge material. The thickness of the SSM is $50 \mathrm{jm}$, a depth that other studies have shown contains the bulk of all surface contaminant enrichments. From the size of the area and the thickness of the microlayer, the volume of water affected by the dredged material is computed and the final resulting concentrations of contaminants in the SSM estimated. Based on a ralationship between total organic and metal contaminant concentrations in the SSM and toxicity (Hardy et al. 1985, Table 1; Hardy et a1. 1986, Tables 7 and 8 and p. 3), the resultant percent mortality to fish (sole) eggs is calculated. 


\section{ASSUMPTIONS AND LIMITATIONS}

The model, in its present form, has several 1 imitations that could be improved through future aquisition of field and laboratory data:

- The model does not include the horizontal transport of SSM contaminants (e.g., movement to the beach).

- The model does not take into account currents or the depth at the disposal site that may affect the area of the resulting "footprint" reaching the surface.

- The model calculates the initial partitioning of dredged material into the SSM, but does not follow the temporal changes in the concentrations of contaminants in the SSM. The model is conservative, because processes that affect the temporal concentration, such as losses due to evaporation, dissolution into the subsurface waters, biological and chemical degradation, and increases caused by gas generation from the sediment, are not included.

- Biological effects on the concentrations in the SSM are not considered. This includes adsorption and settling out on fecal pellets, bioturbation and feeding by organisms in the S5M. The computed toxic effects on fish larval hatch assume that the embryos are exposed to the microlayer contamination throughout their 6- to 7 -day period of embryonic development. This may very well represent a realistic situation, because once trapped in an organic surface film, the emoryos are likely to remain in association with the film. ATso, toxicity is computed using on 1 y PAH and metal concentrations; other contaminants are not included in the model that is used to predict fish larval hatching success. 


\section{SAMPLE SCENARIOS}

Four sample scenarios have been computed (see Appendix C). All use inputs of $1500 \mathrm{yd}^{3}$ of dredged material with a specific gravity of $1.350 \mathrm{~g} / \mathrm{mL}$ and a radius for the disposal area of $900 \mathrm{ft}$. Typical contaminant concentrations on dredged material and baseline concentrations in the microlayer of Elliott Bay (Hardy et al. 1985, 1986) are used. The floatable fraction was varied between $1 \times 10^{-11}$ and $1 \times 10^{-6}$. The results of tests 1 to 4 suggest that significant toxicity to fish eggs from the addition of dredged material would not occur if the floatable fraction is less than $1 \times 10^{-10}$ (tests 1 and 2). Assuming no existing contamination, larval hatch is about $84 \%$. When the mean microlayer contaminant concentrations already present in Elliott Bay are used as input variables, predicted live larval hatch is reduced to $54 \%$ and in some areas would be even lower. However, if the floatable fraction is as great as $1 \times$ $10^{-8}$, dredge disposal would decrease larval hatch in the disposal area to 3 to $22 \%$ (test 3 ). At $1 \times 10^{-6}$ floatable fraction, no tarvae would survive in the disposal area (test 4 ).

In addition to single dredge disposal events, the model can be used to compute average enrichments over longer periods of time or over large areas (e.g., the annual 6-day average disposal contribution to an area the size of Elliott Bay). 


\section{RELATIONSHIP TO WATER QUALITY CRITERIA}

How do the predicted microlayer concentrations resulting from dredge material disposal compare to water quality criteria? The quality criteria for metals generally range from 2 to $58 \mathrm{\mu g} / \mathrm{L}$ and for PCBs is $0.001 \mathrm{\mu g} / \mathrm{L}$ (see Table 1). U.S. Environmental Protection Agency (EPA) water quality criteria are not available for most organic compounds. Criteria for aquatic effects have not been established for PAHs, but the EPA suggests that the level where adverse effects may be expected is above $300 \mu \mathrm{g} / \mathrm{L}$ of total PAH. Available information suggests that exposure of eggs and larvae of fish and shelifish to concentrations of petroleum hydrocarbons greater than $100 \mu \mathrm{g} / \mathrm{L} \mathrm{will} \mathrm{result} \mathrm{in}$ harmful effects (Table 1). When herring eggs are exposed to crude oi1, droplets adhere to the surface of the eggs and, at exposure concentrations of 4 to $761 \mathrm{~kg} / \mathrm{L}$, hatched larvae showed an increased incidence of abnormalities (Pearson et al. 1985). Reduced or abnormal larval hatch of fish eggs can result from exposure to concentrations of an individual PAH compound, benzo(a)pyrene, as low as 0.1 to $0.2 \mu \mathrm{g} / \mathrm{L}$ (Table 1 ).

The sole egg bioassay, on which our model of microlayer effects is based, provides a very sensitive measure of effects. If sole eggs were exposed for 6 days to a mixture containing all the metals at their EPA water quality criteria concentrations shown in Table 1 , the model would predict about a $40 \%$ decrease in live larval hatch from these metals alone. The sample dredge disposal scenarios (Appendix C), suggest that scenarios (tests) 1 and 2 would have no effect in increasing microlayer contaminant concentrations. In tests 2 and 3, microlayer concentrations of both metals, PAHs and PCBs reach concentrations that are both expected to be harmful from past studies (see Table 1) and that are also predicted to reduce live larval hatch by our own model. 
TABLE 1. Effects of Contaminants on Marine Organisms

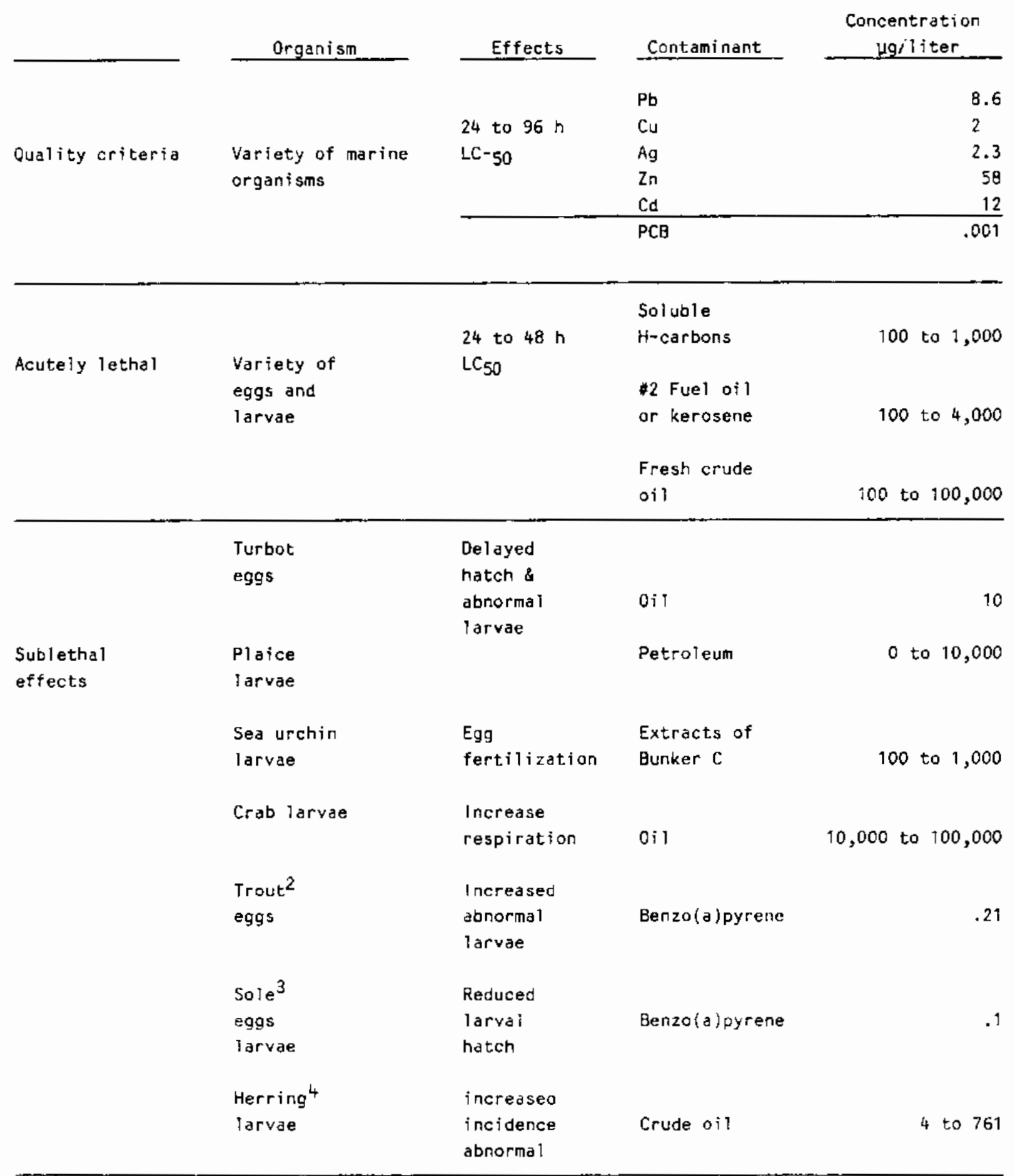

1 U.S. EPA 1976.

2 Hannah et at. $i 982$.

3 Hose et al. 1982.

4 Pearson et al. 1985. 


\section{REFERENCES}

Hannah, J. B., J. E. Hose, M. L. Landolt, B. S. Miller, S. P. Felton and W. T. Iwaoka. 1982. "Benzo(a)pyrene Induced Morphologic and Developmental Abnormalities in Rainbow Trout." Arch. Environ. Contam. Toxicol. 11:727-734.

Hardy, J. T. 1982. "The Sea-Surface Microlayer: Biology, Chemistry and Anthropogenic Enrichment." Prog. Oceanog. 11:307-322.

Hardy, J. T., C. H. Apts, E. A. Crecelius and N. S. Bloom. 1985. "Sea-surface Microlayer Metals Enrichments in an Urban and Rural Bay." Estuar. Coastal, Shelf Sci. 20:299-312.

Hardy, J. T., E. A. Crecelius and R. Kocan. 1986. Concentration and Toxicity of Sea-surface Contaminants in Puget Sound. Final Report CY 1985 to Nationa? Oceanic and Atmospheric Administration, OAD, Pacific Northwest Laboratory, Richland, Washington.

Hose, J. E., J. B. Hannah, D. Dijulio, M. L. Landolt, B. S. Miller, W. T. Iwaoka and S. P. Felton. 1982. "Effects of Benzo(a)pyrene on Early Development of Flatfish." Arch. Environ. Contam. Toxicol. 11:167-171.

Pearson, W. H., D. L. Woodruff, S. L. Kiesser, G. W. Fellingham and R. A. Elston. 1985. Oil Effects on Spawning Behavior and Reproduction in Pacific Herring (Clupea harengus palTasi). Final Report prepared by Marine Research Laboratory, Sequim, Washington for the American Petroleum Institute, Environmental Affairs Department, Washington D.C.

U.S. EPA. 1976. Quality Criteria for Water. U.S. Environmental Protection Agency, Washington, D.C. $256 \mathrm{pp}$. 
APPENDIX A

FLOW CHART OF MOUEL 
Flow Chart: Main Program DREDGE

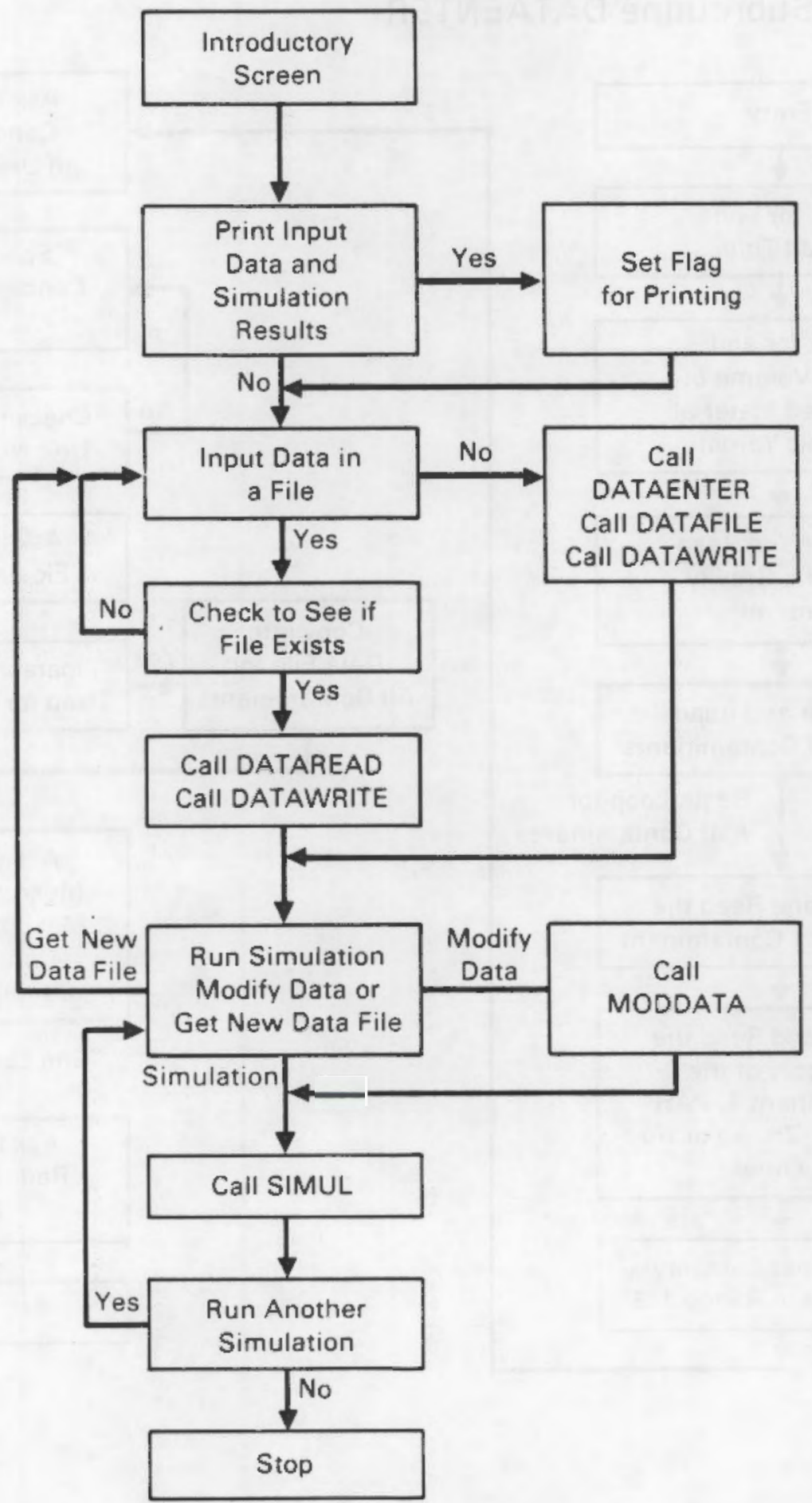

A. 1 


\section{Flow Chart: Subroutine DATAENTER}
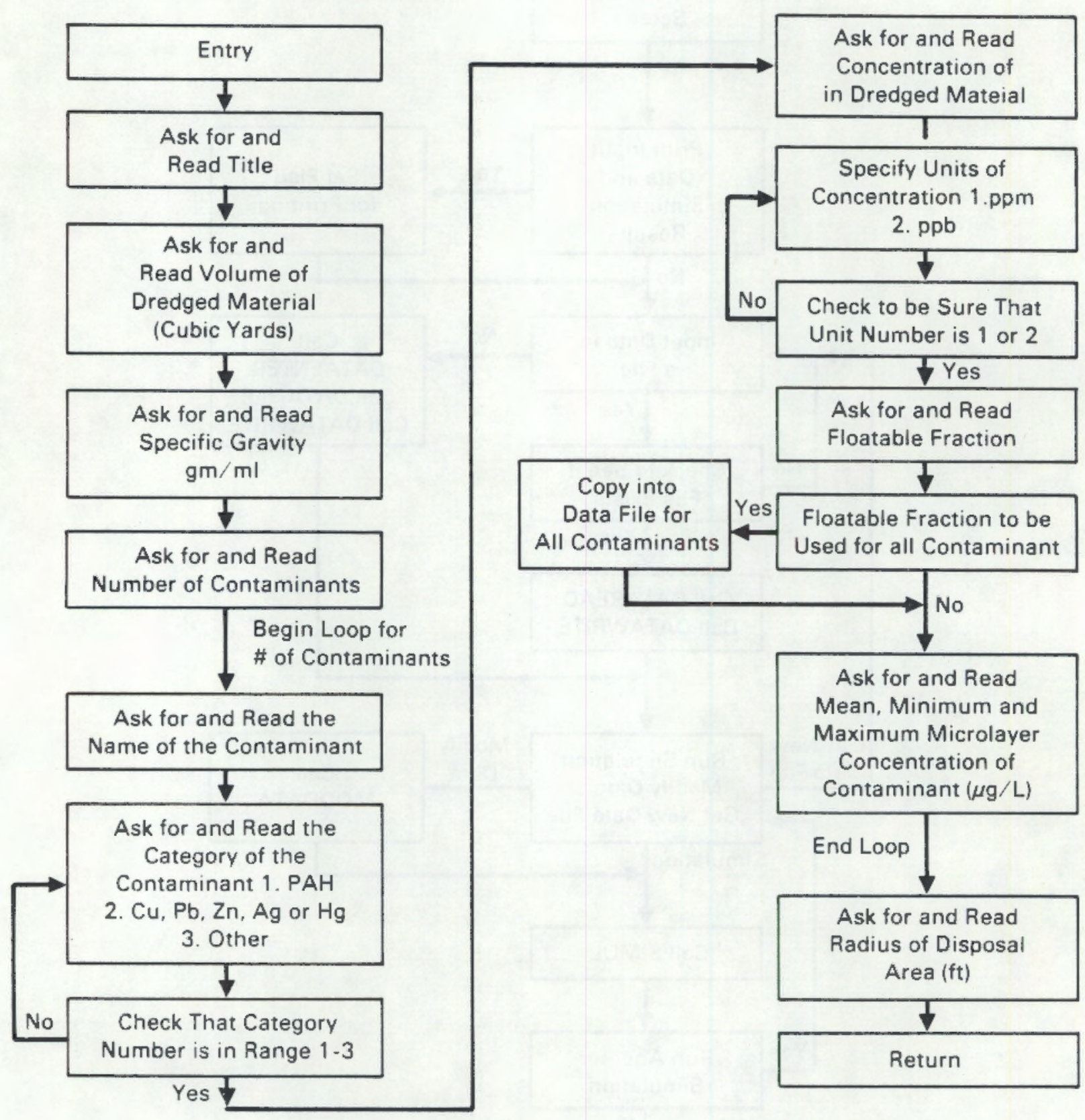

A. 2 


\section{Flow Chart: Subroutine DATAFILE}

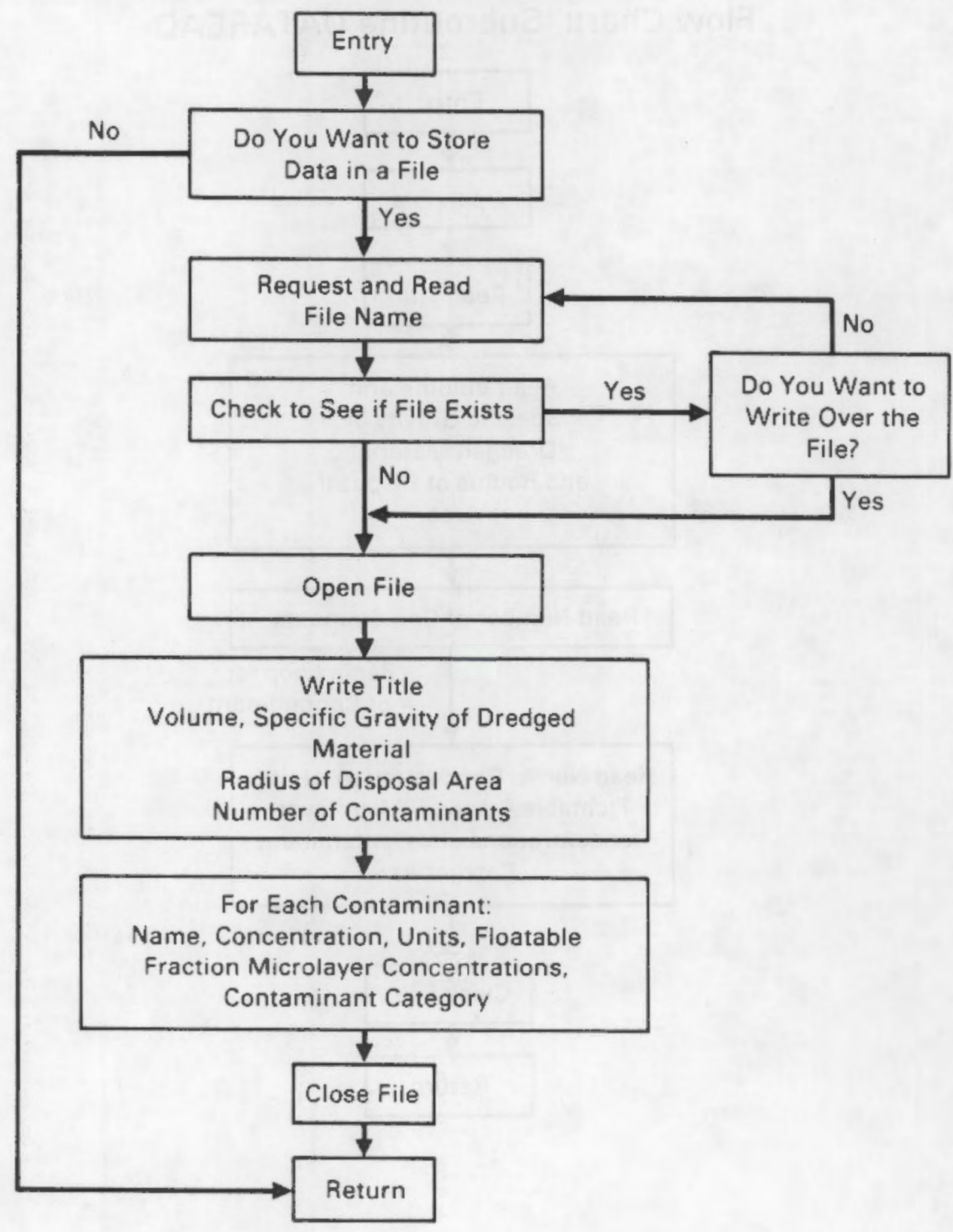


Flow Chart: Subroutine DATAREAD

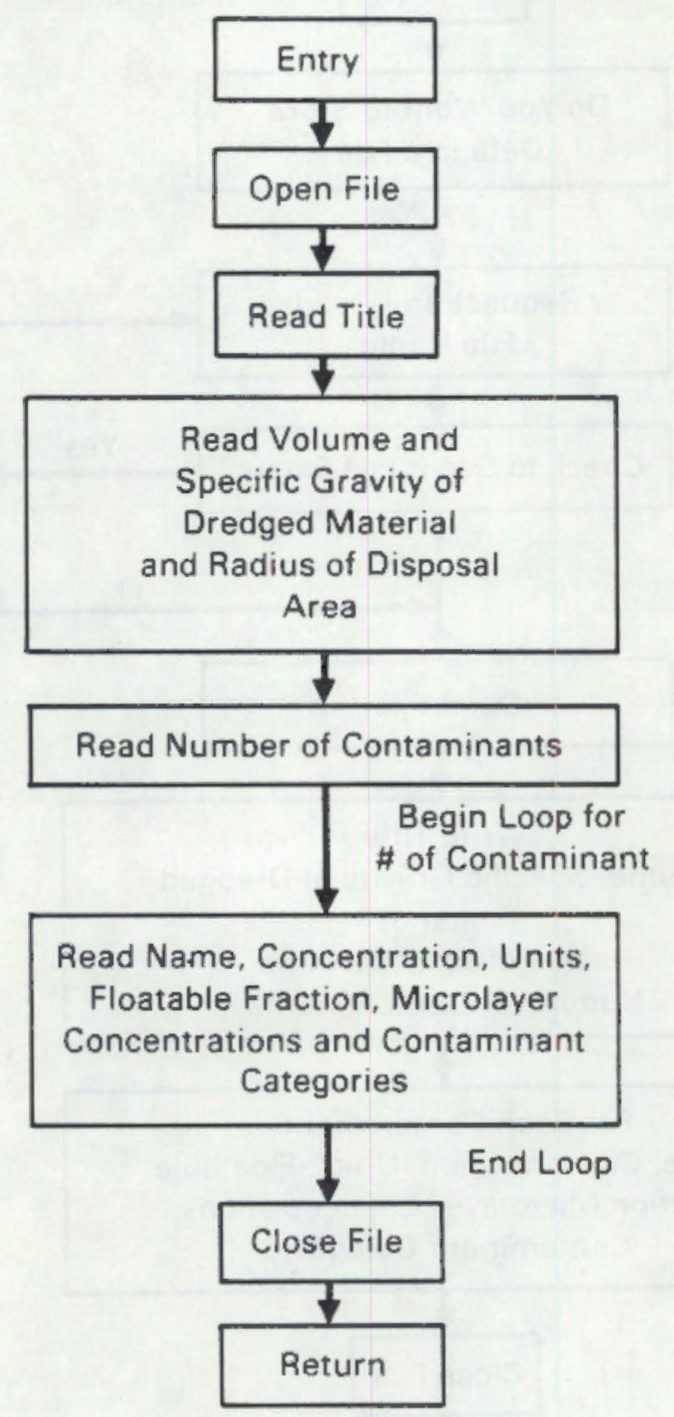

A. 4 


\section{Flow Chart: Subroutine DATAWRITE}

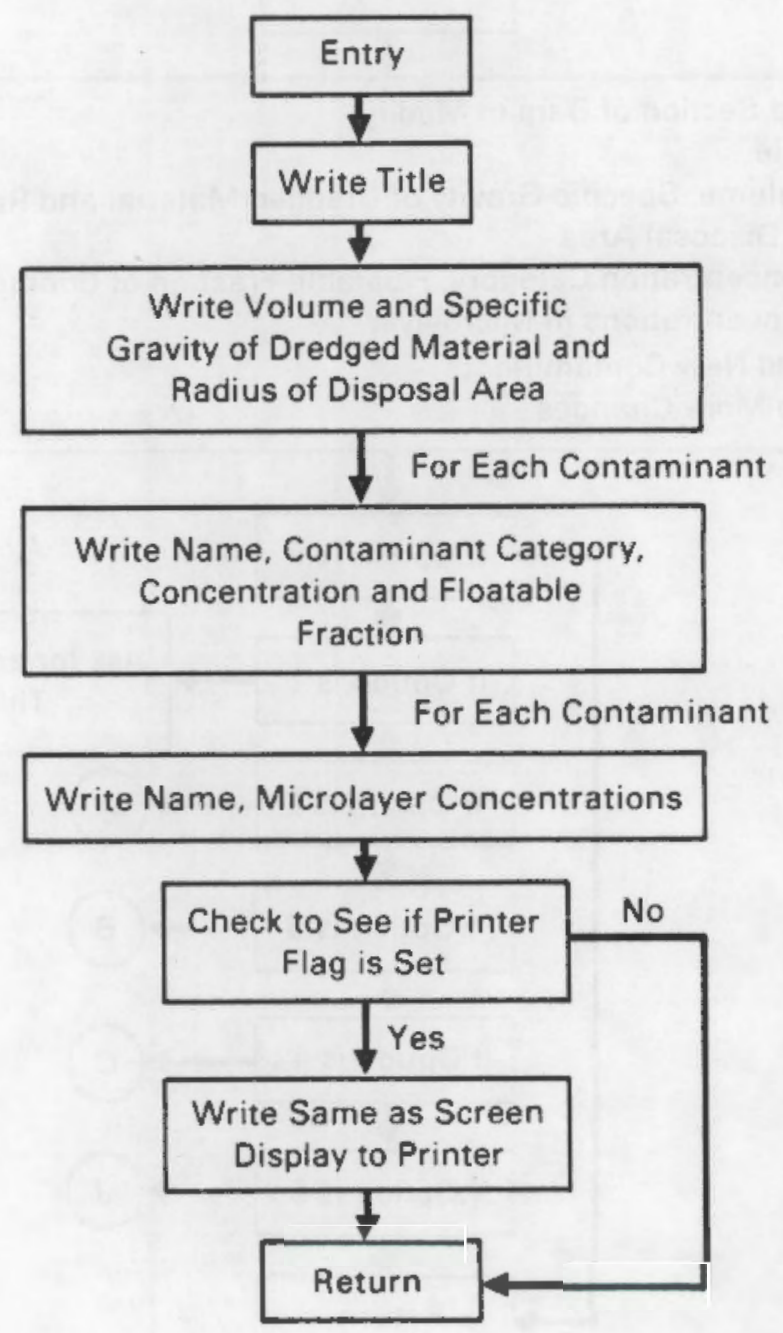

A. 5 


\section{Flow Chart: Subroutine MODDATA}

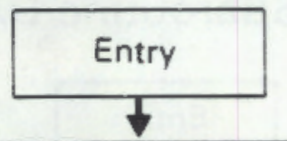

Choose Section of Data to Modify

1. Title

2. Volume, Specific Gravity of Dredged Material and Radius of Disposal Area

3. Concentration Category, Floatable Fraction of Contaminant

4. Concentrations in Microlayer

5. Add New Contaminants

6. No More Changes

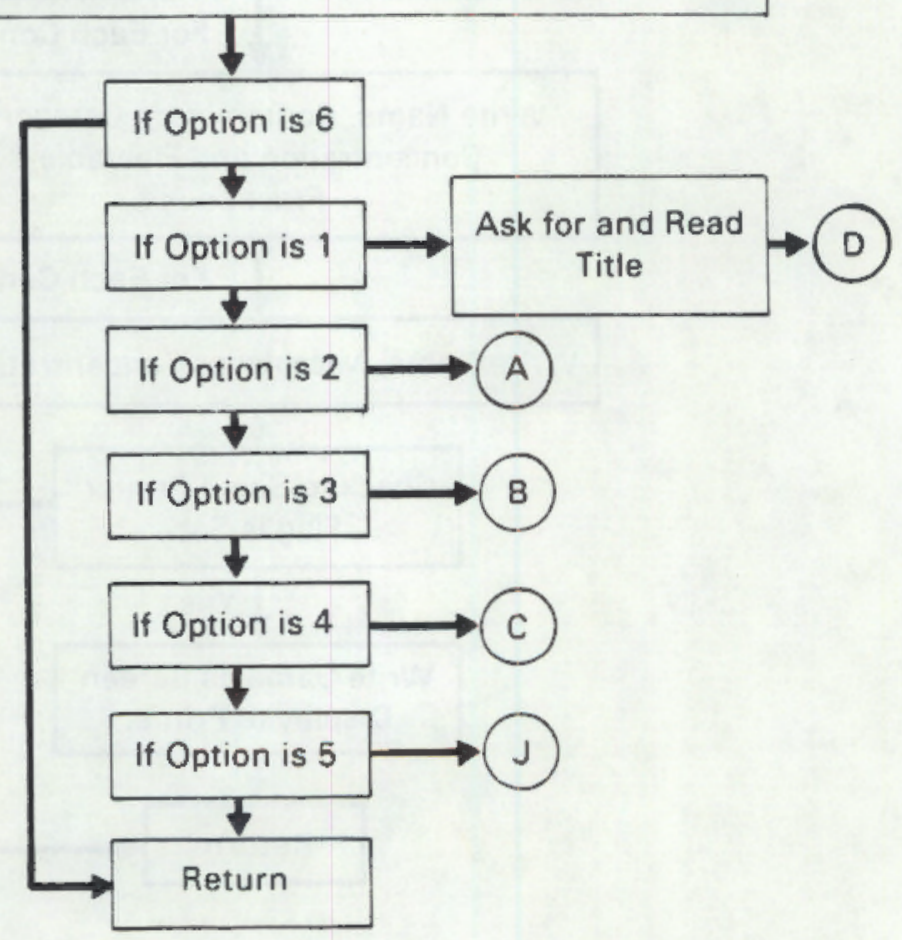




\section{Option is 2}

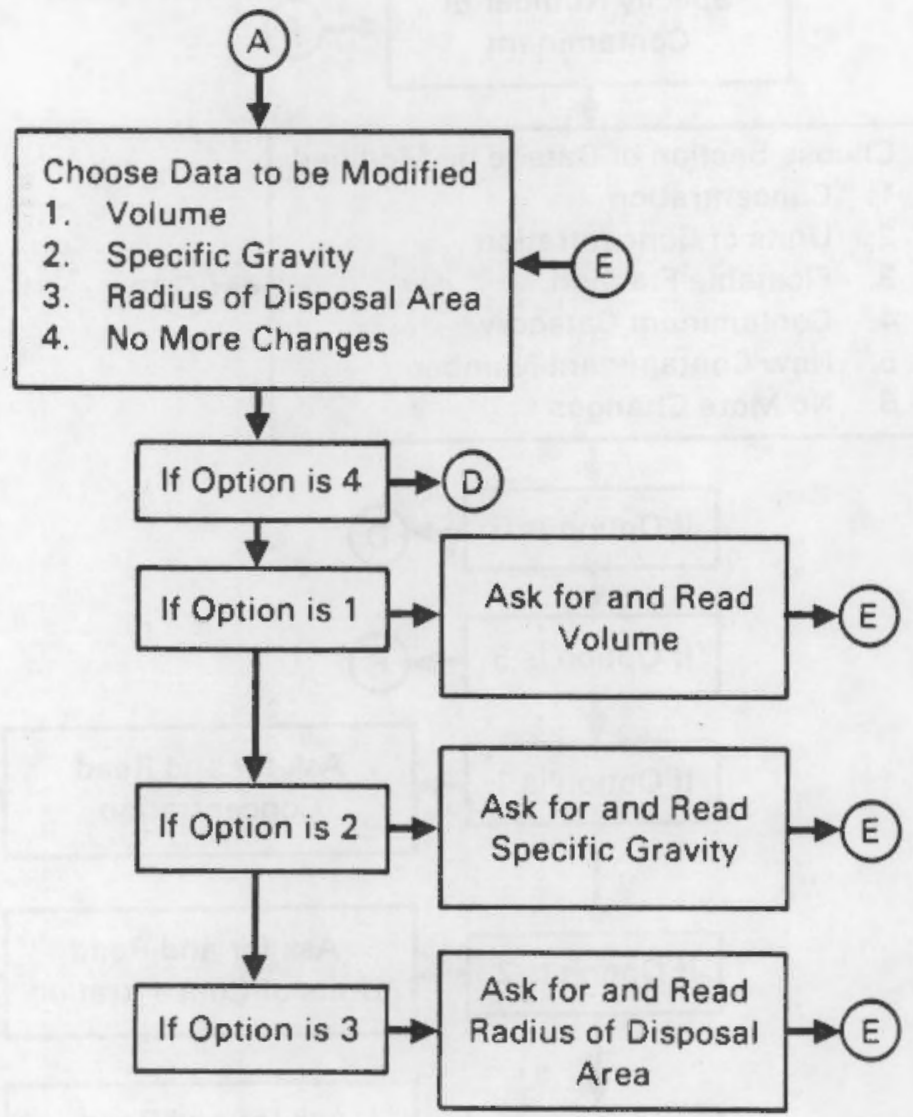

A. 7 


\section{Option is 3}

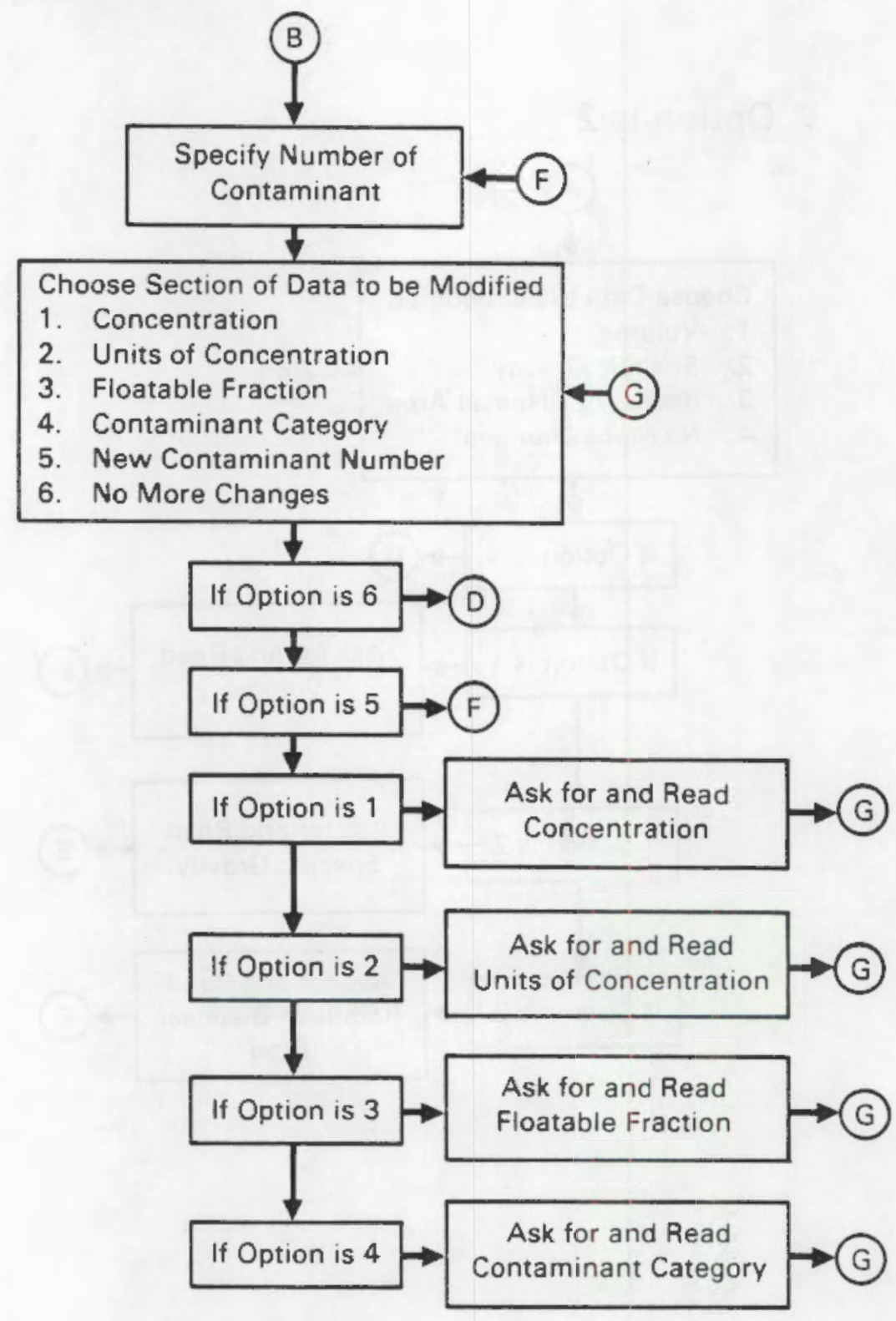


Option is 4

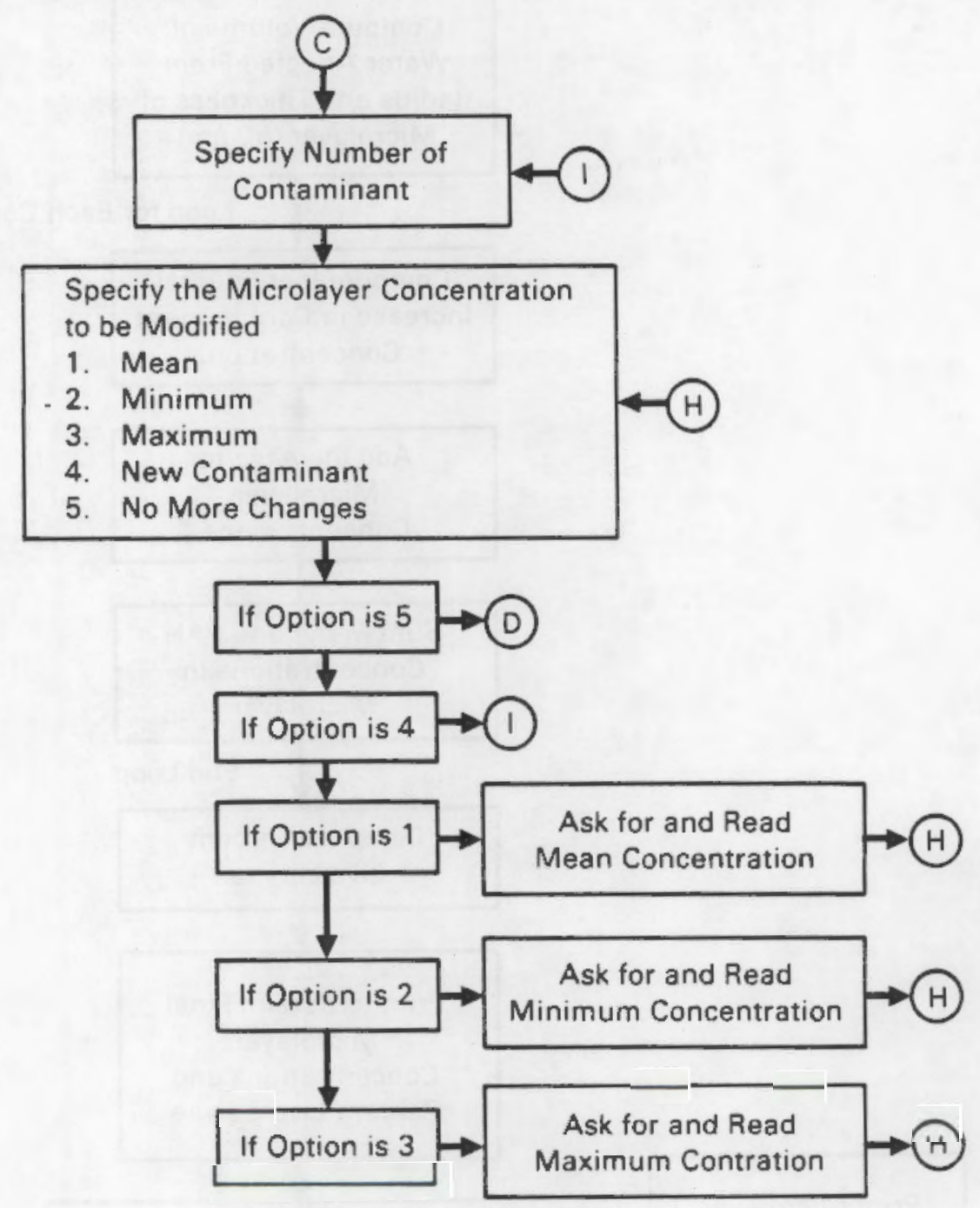

A. 9 


\section{Flow Chart: Subroutine SIMUL}

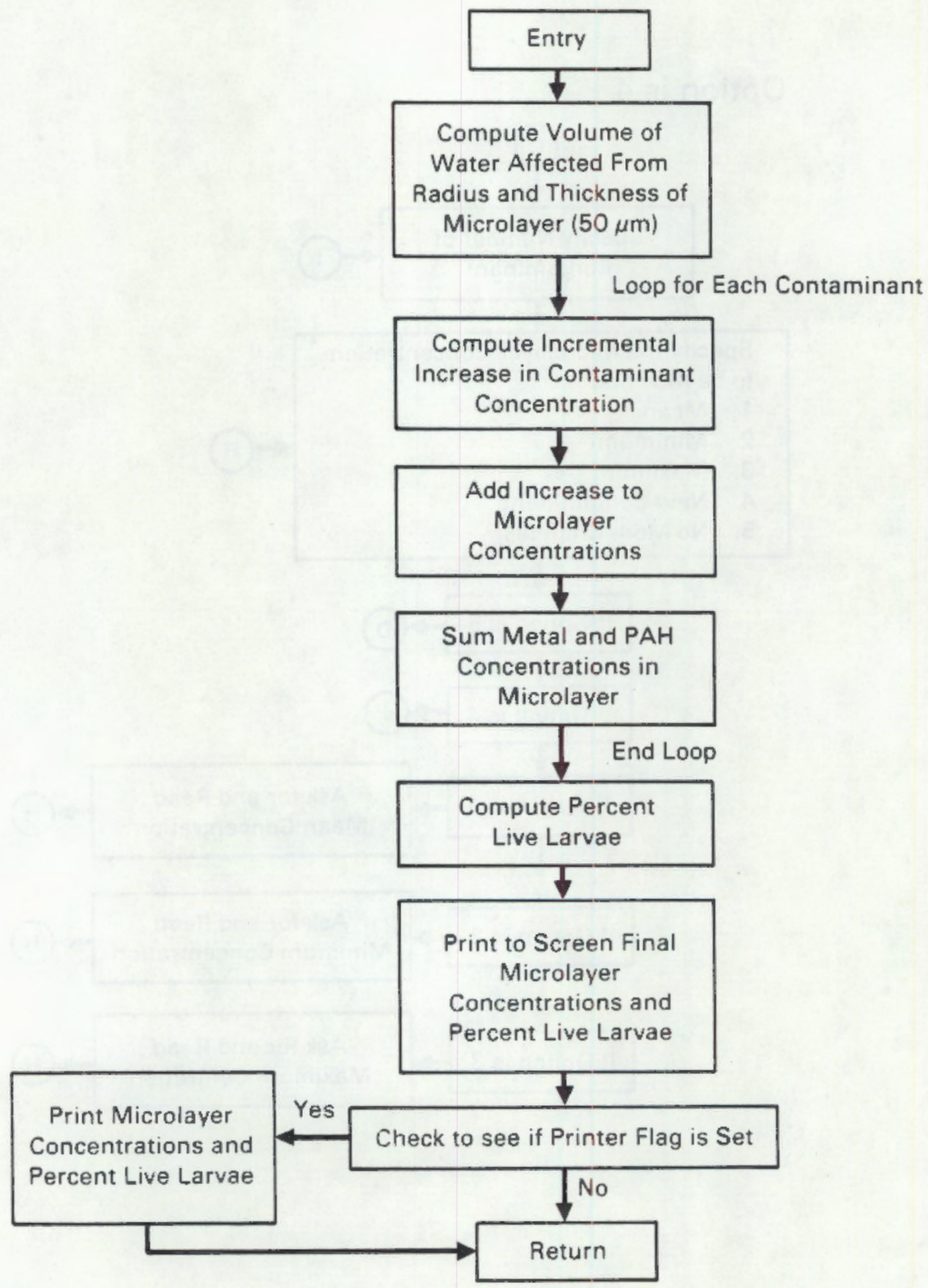




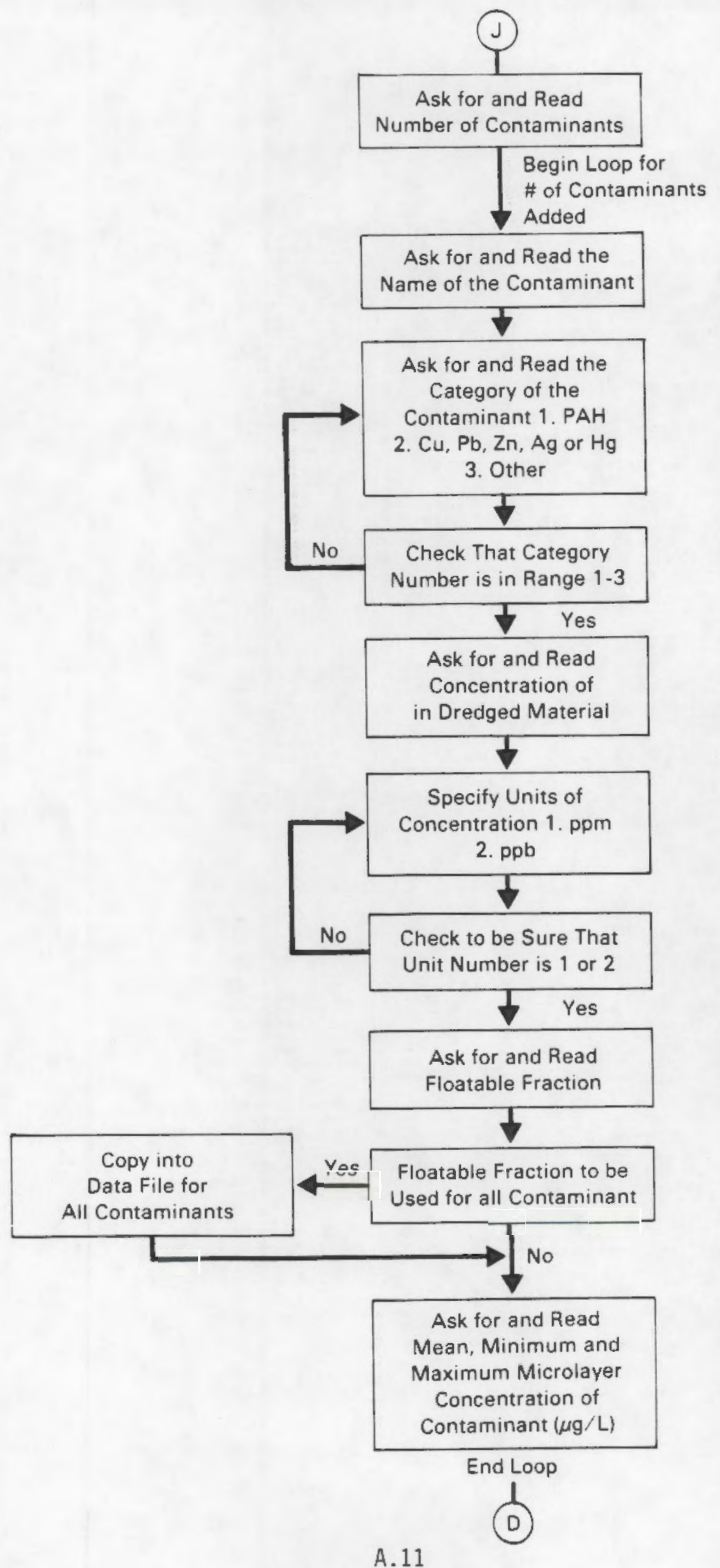


APPENDIX B

DREDGE PROGRAM 


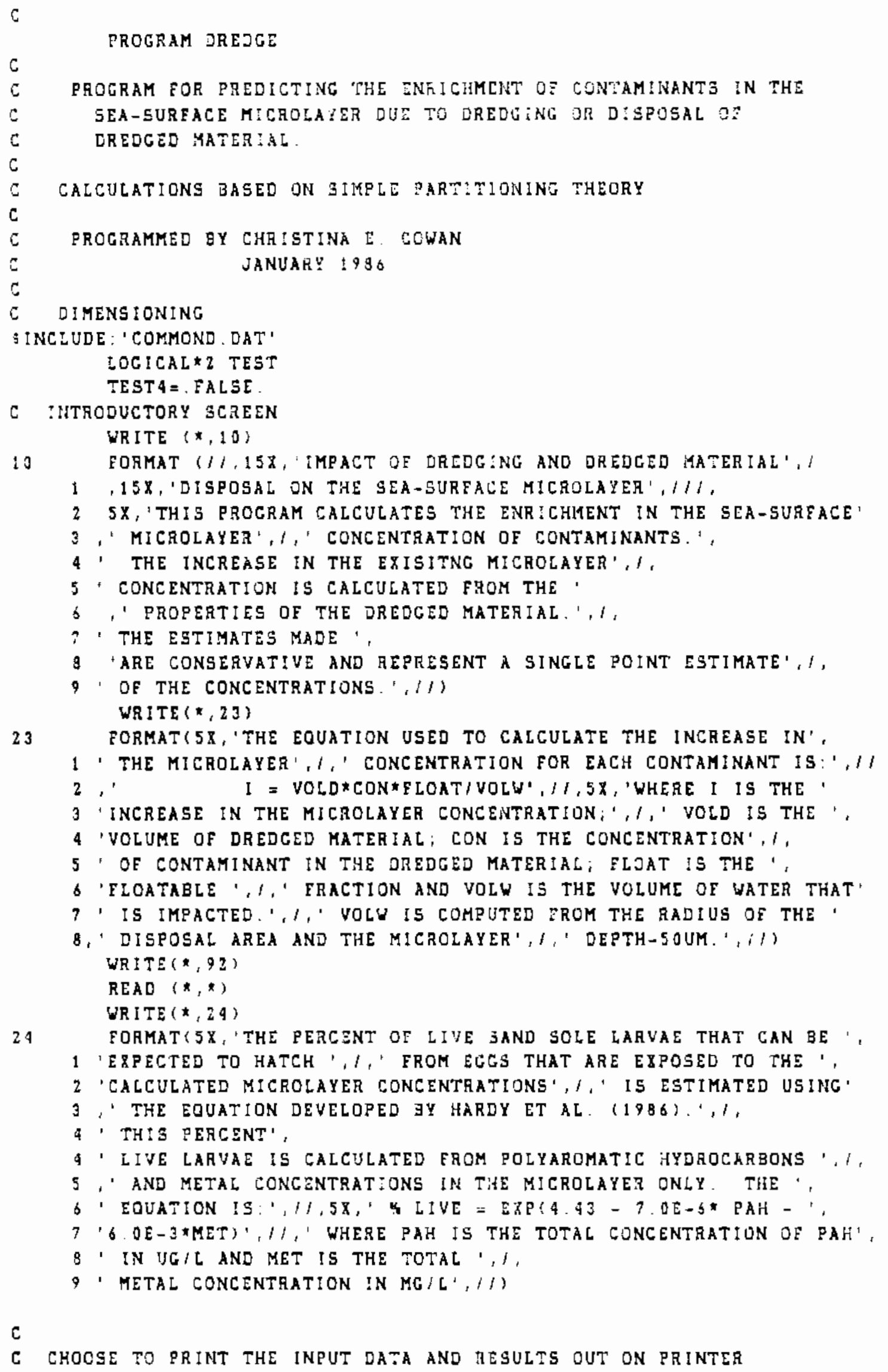




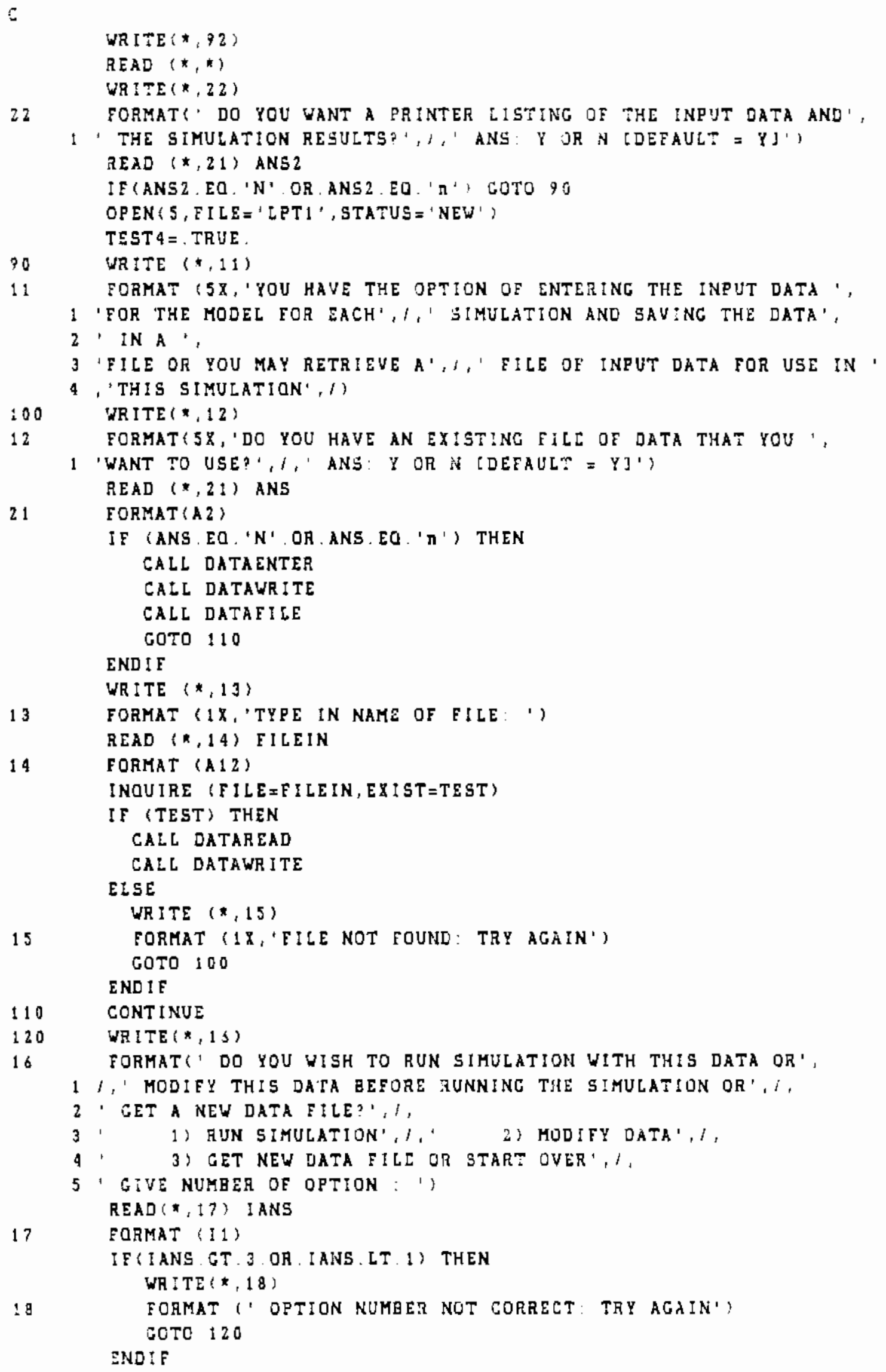




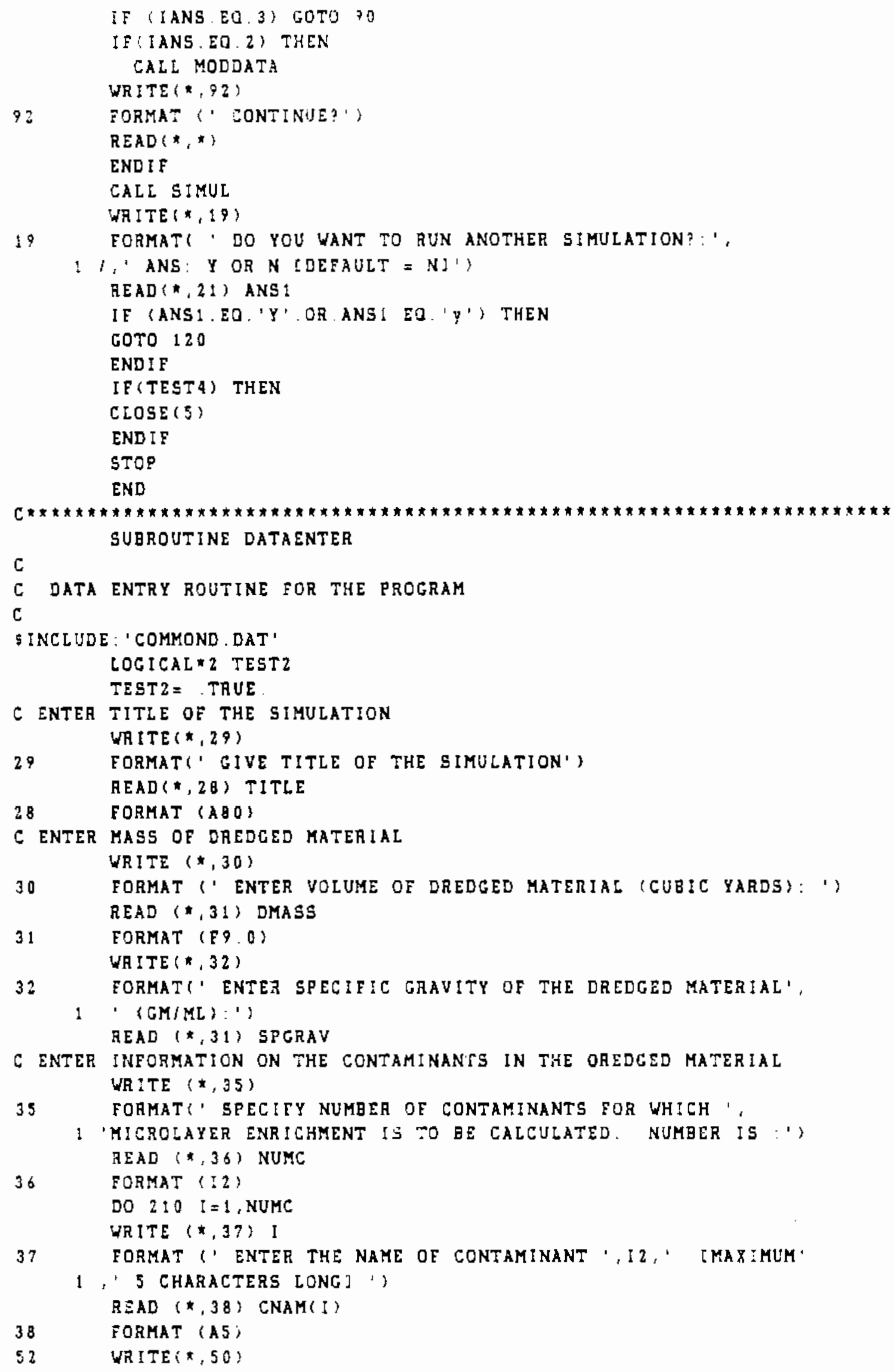




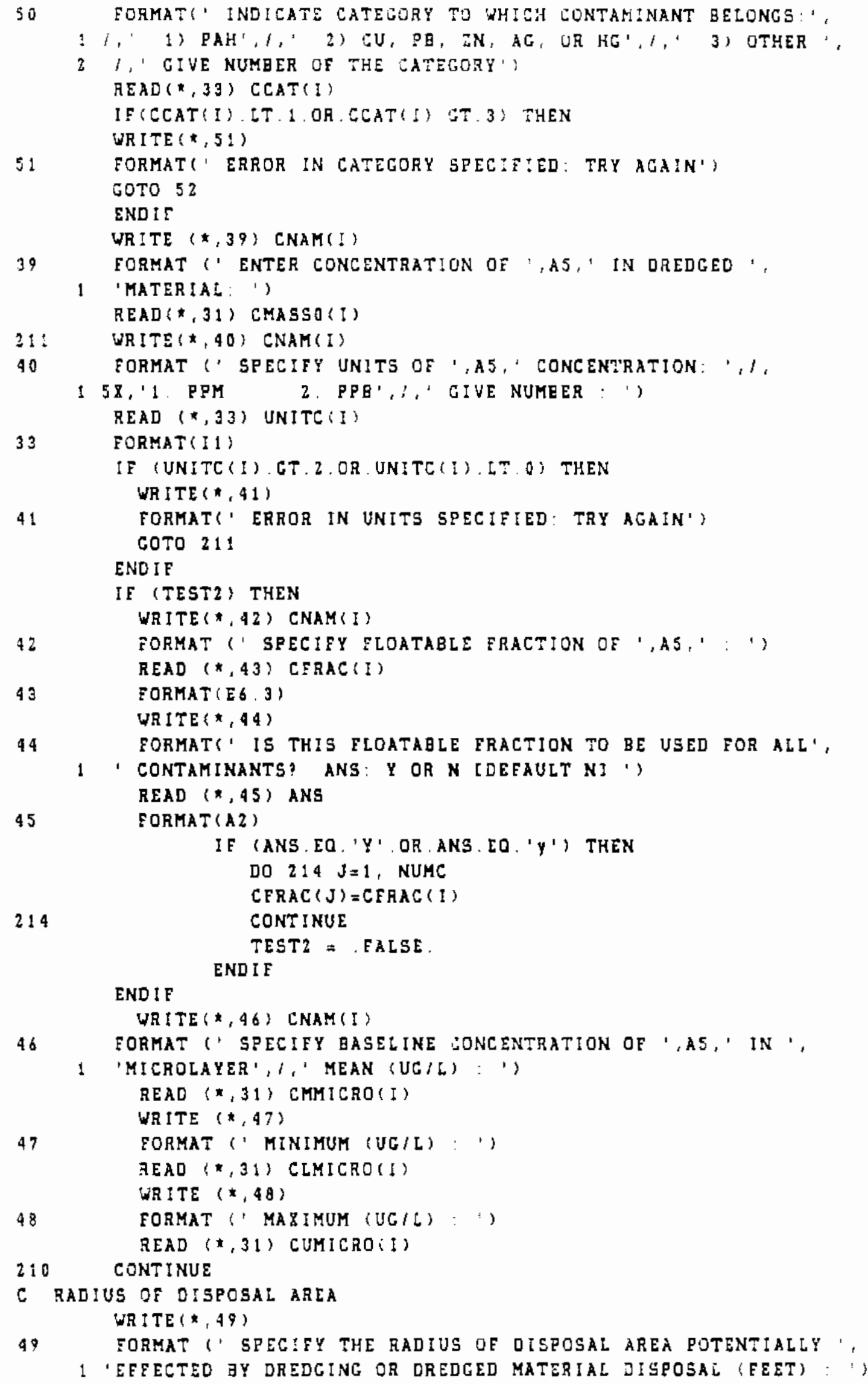




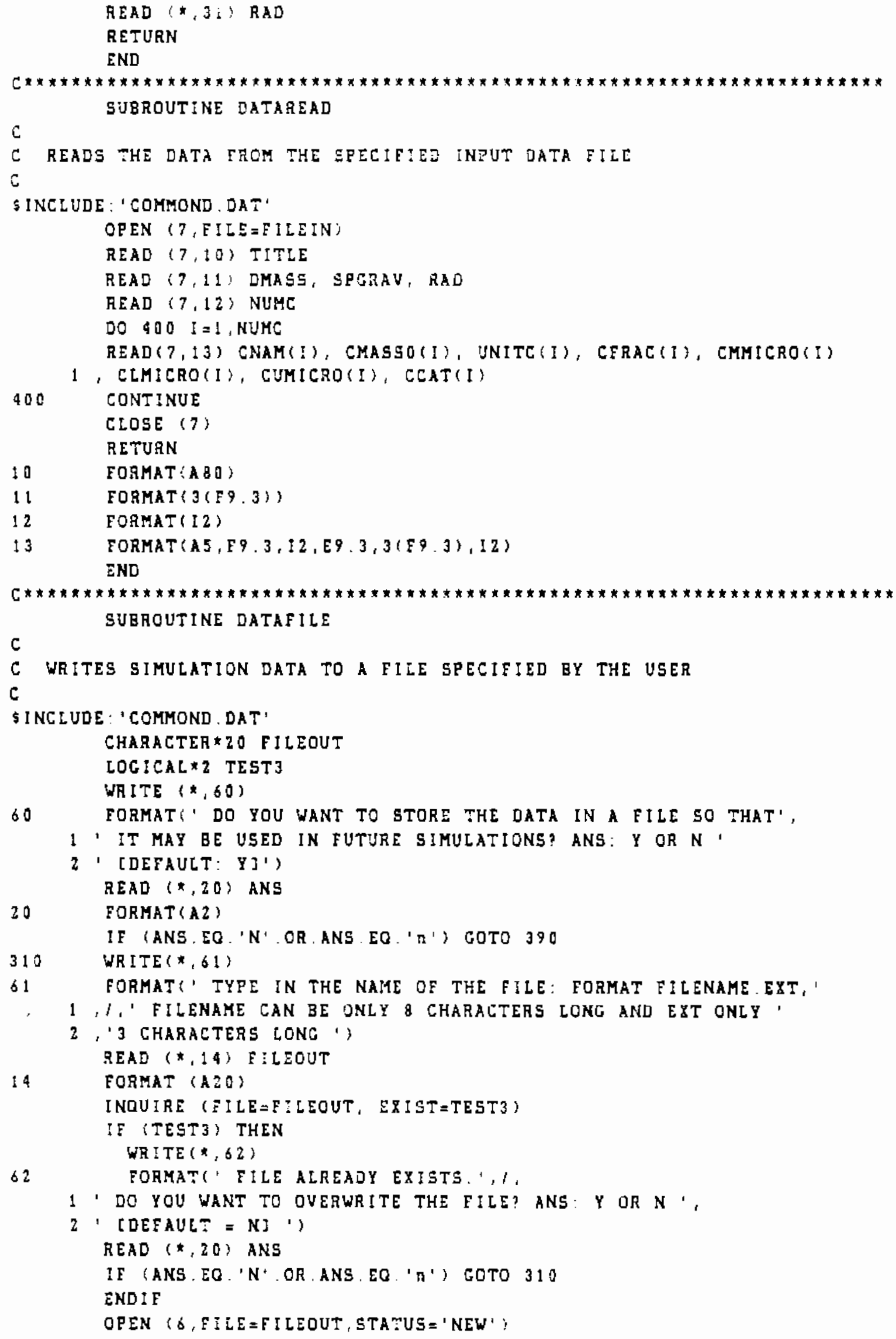




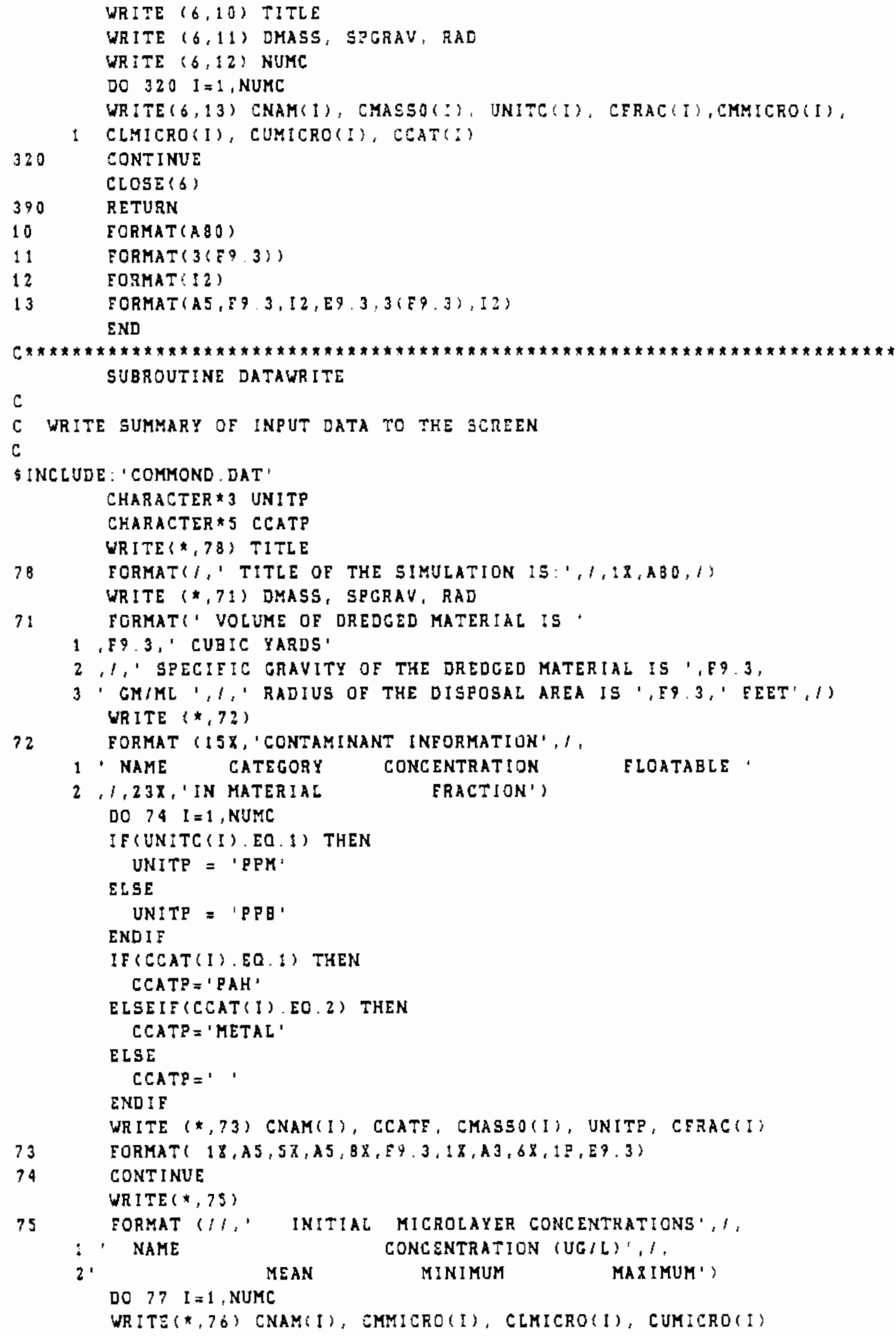




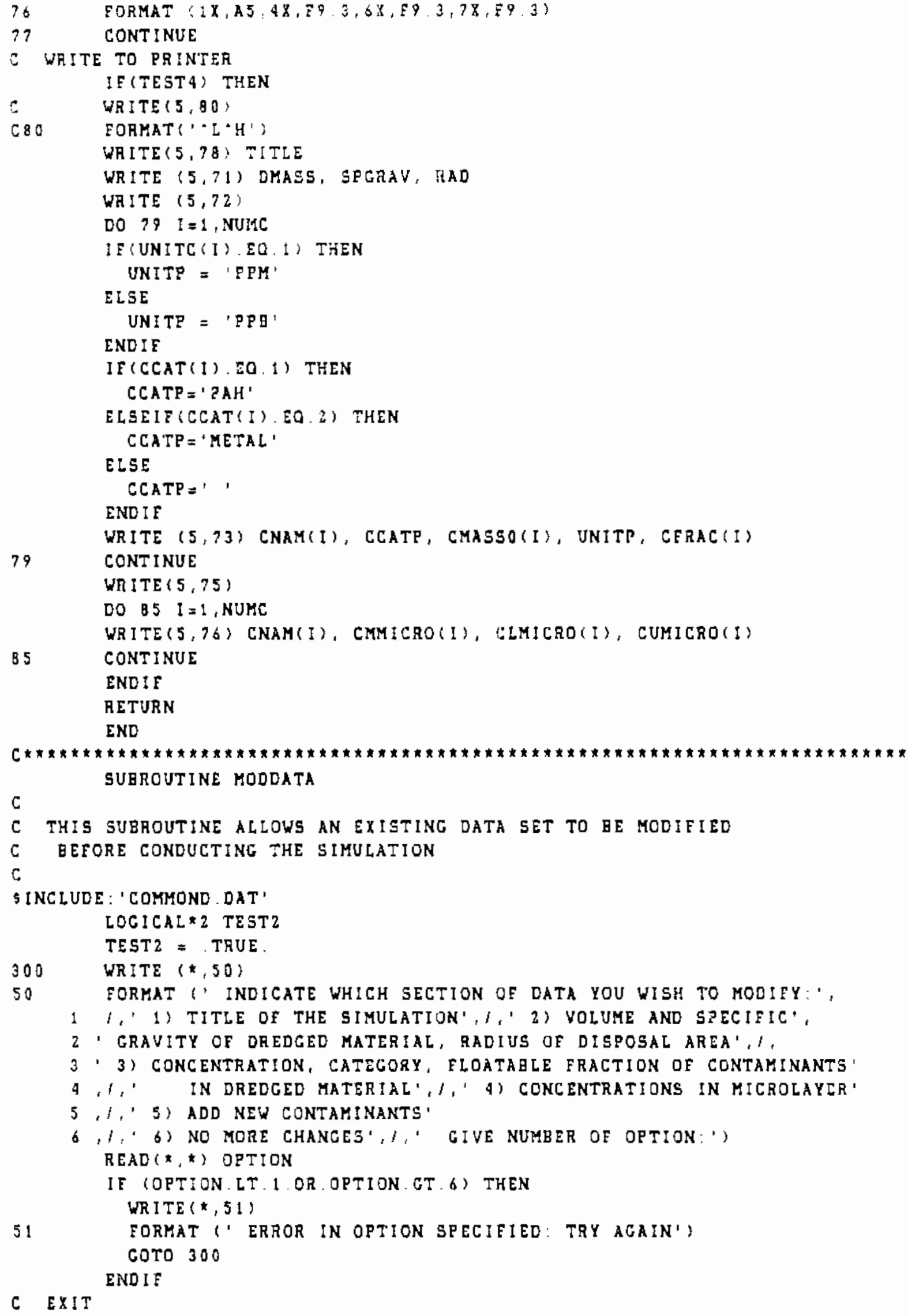




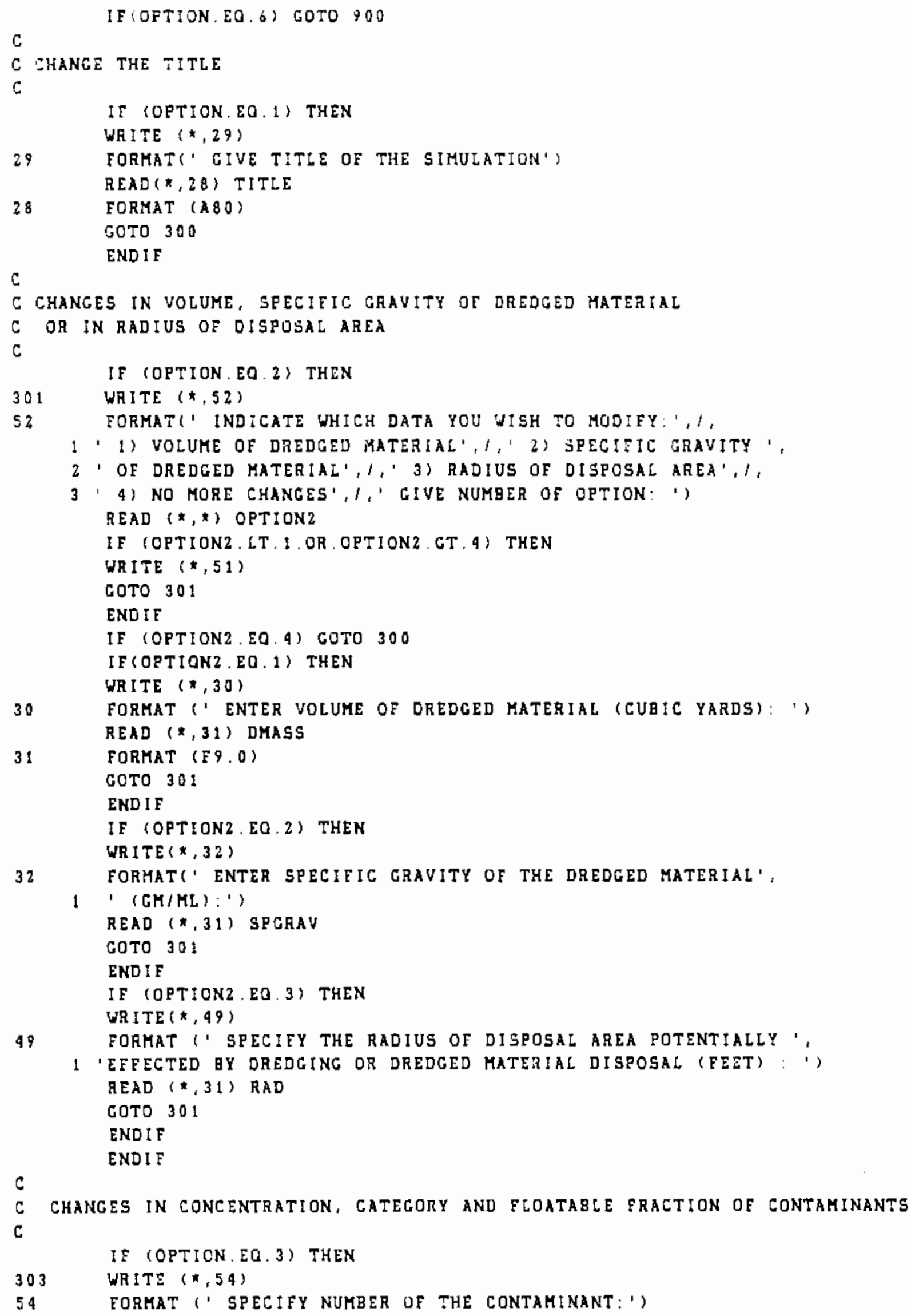




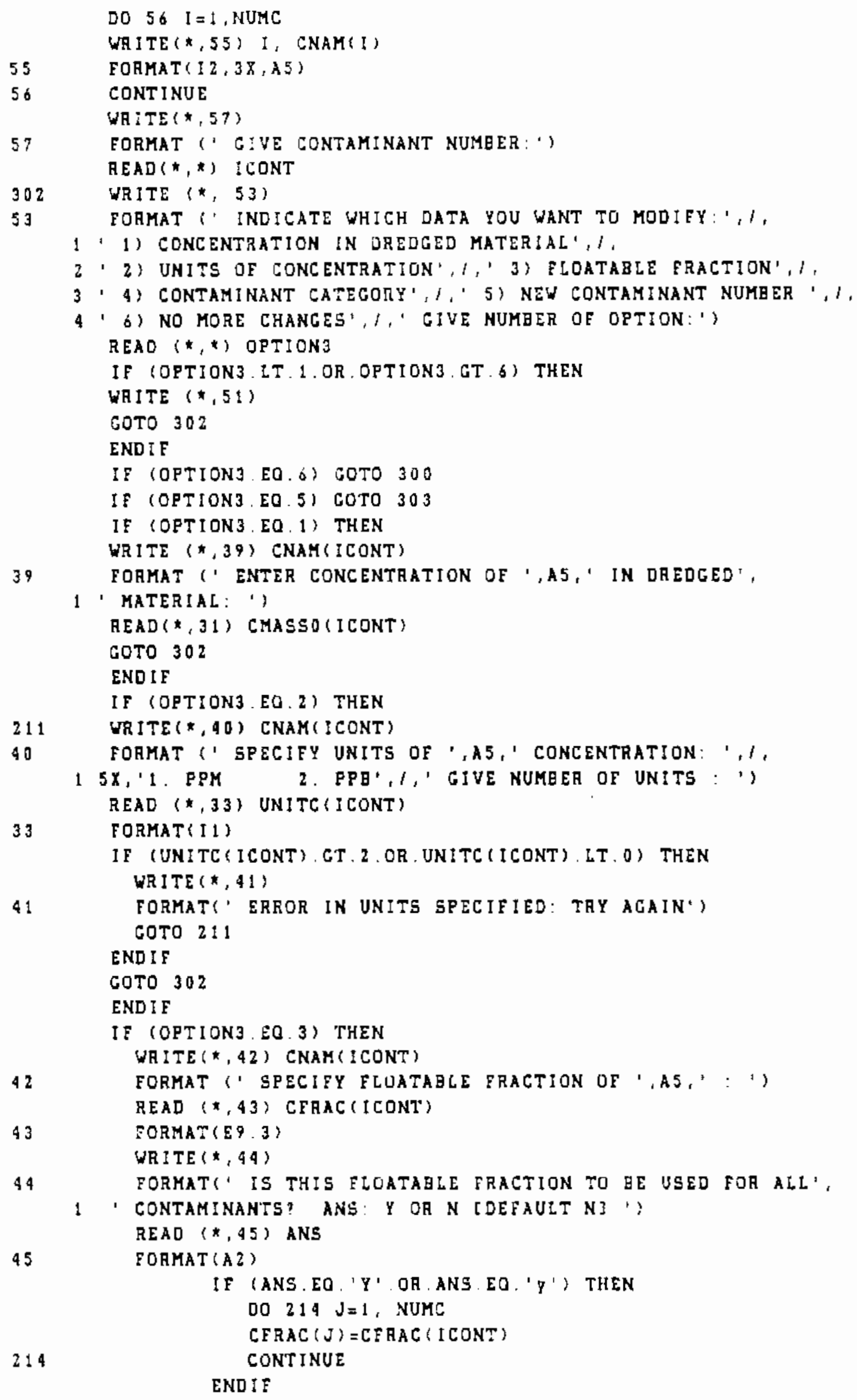




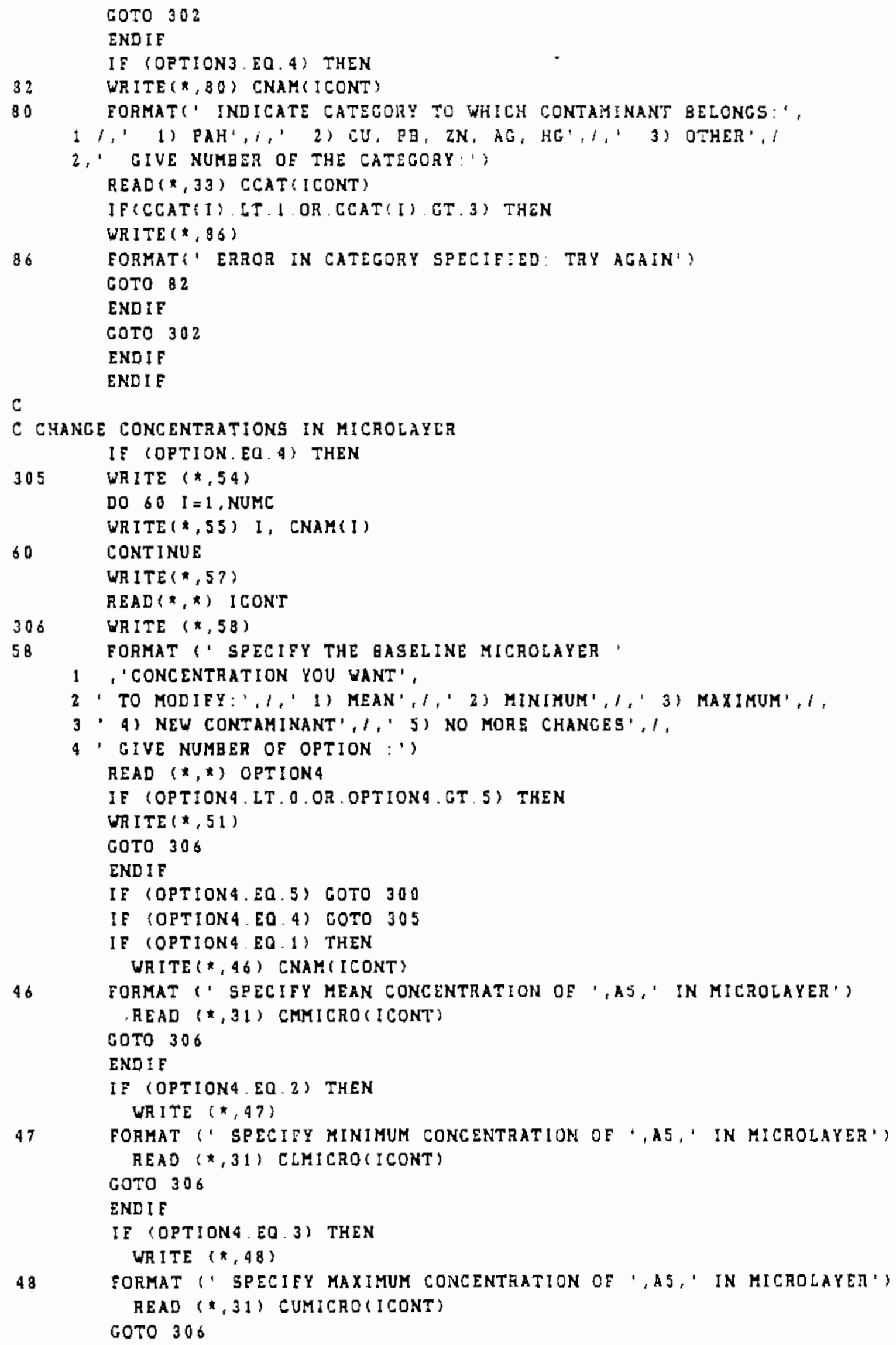




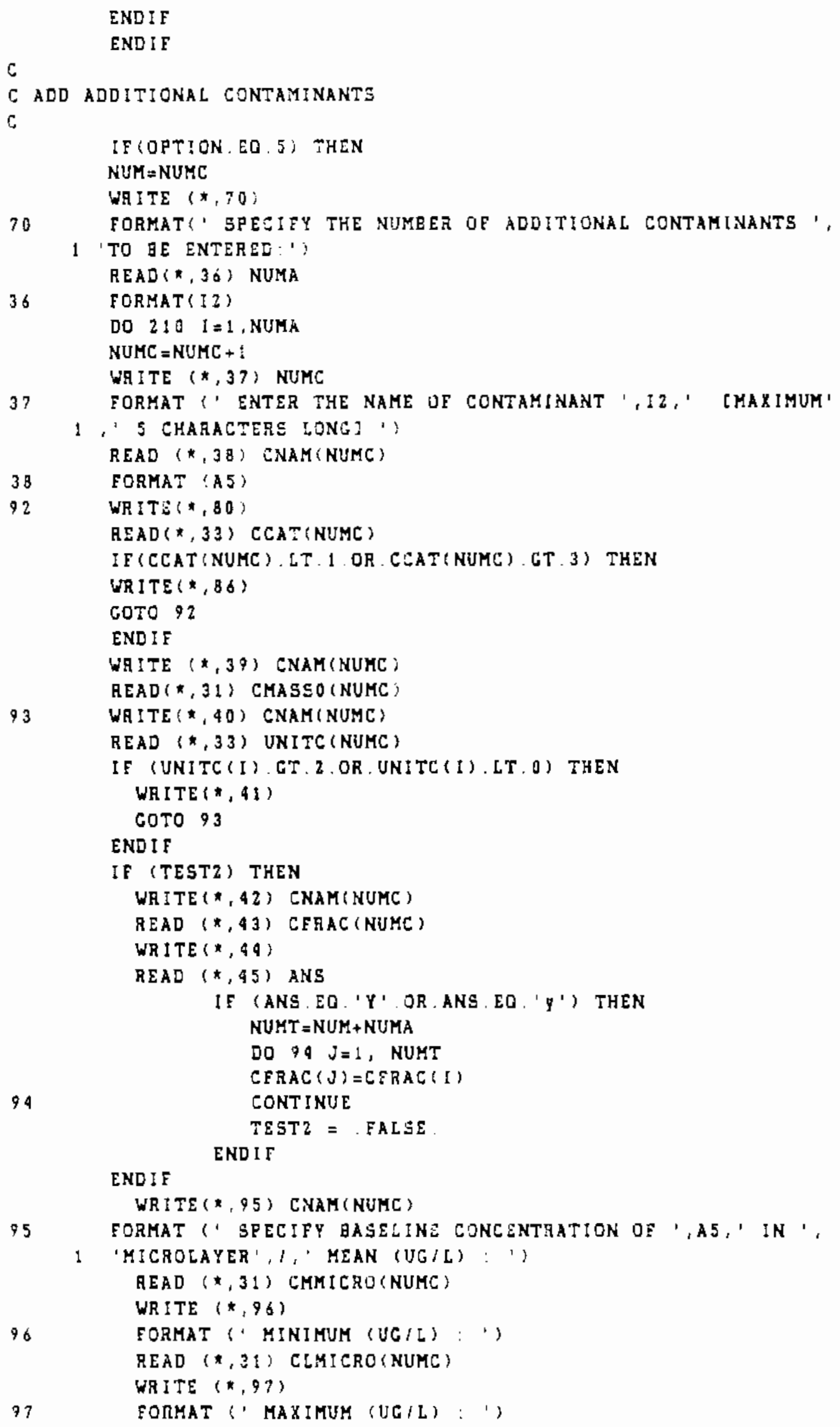




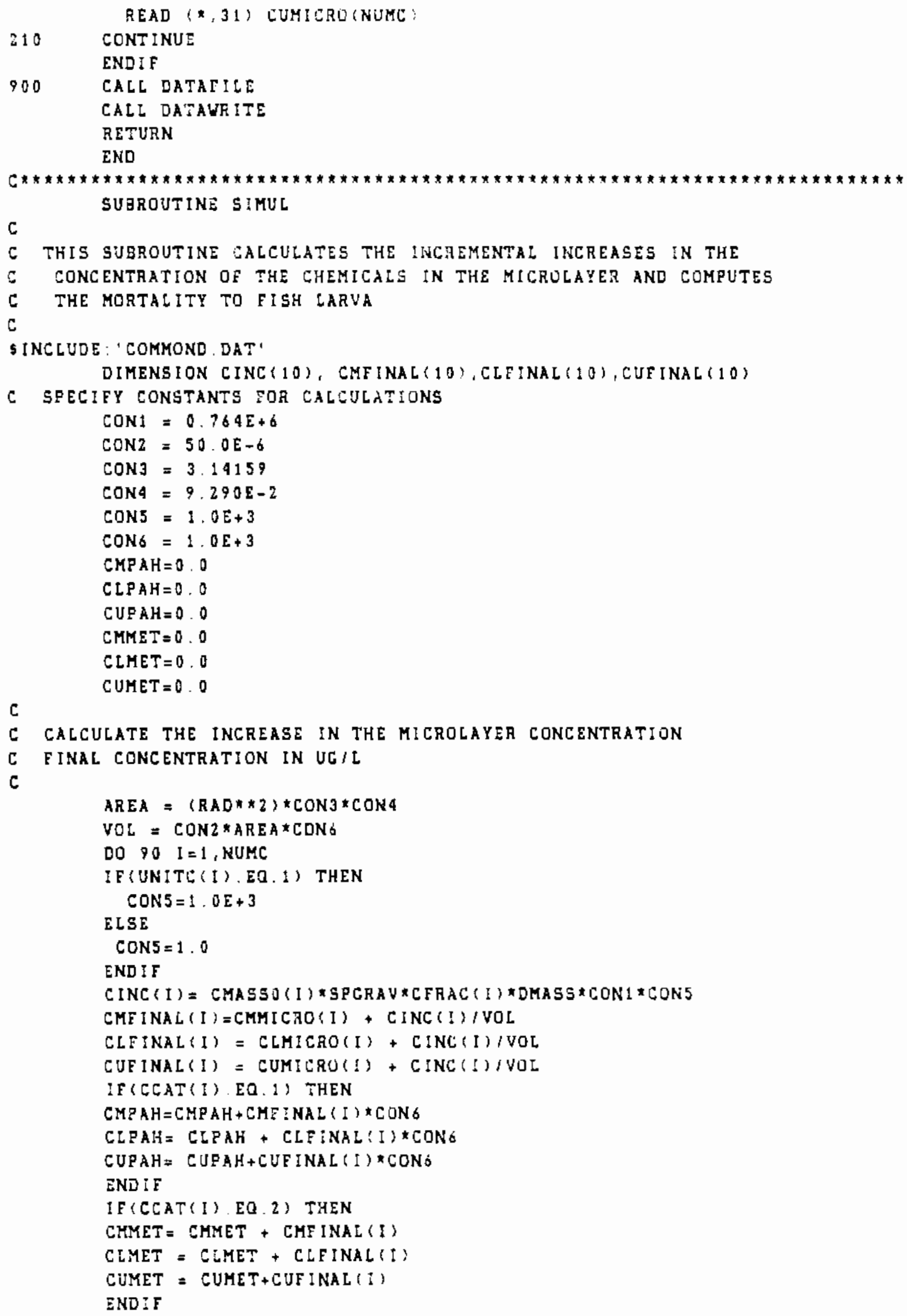




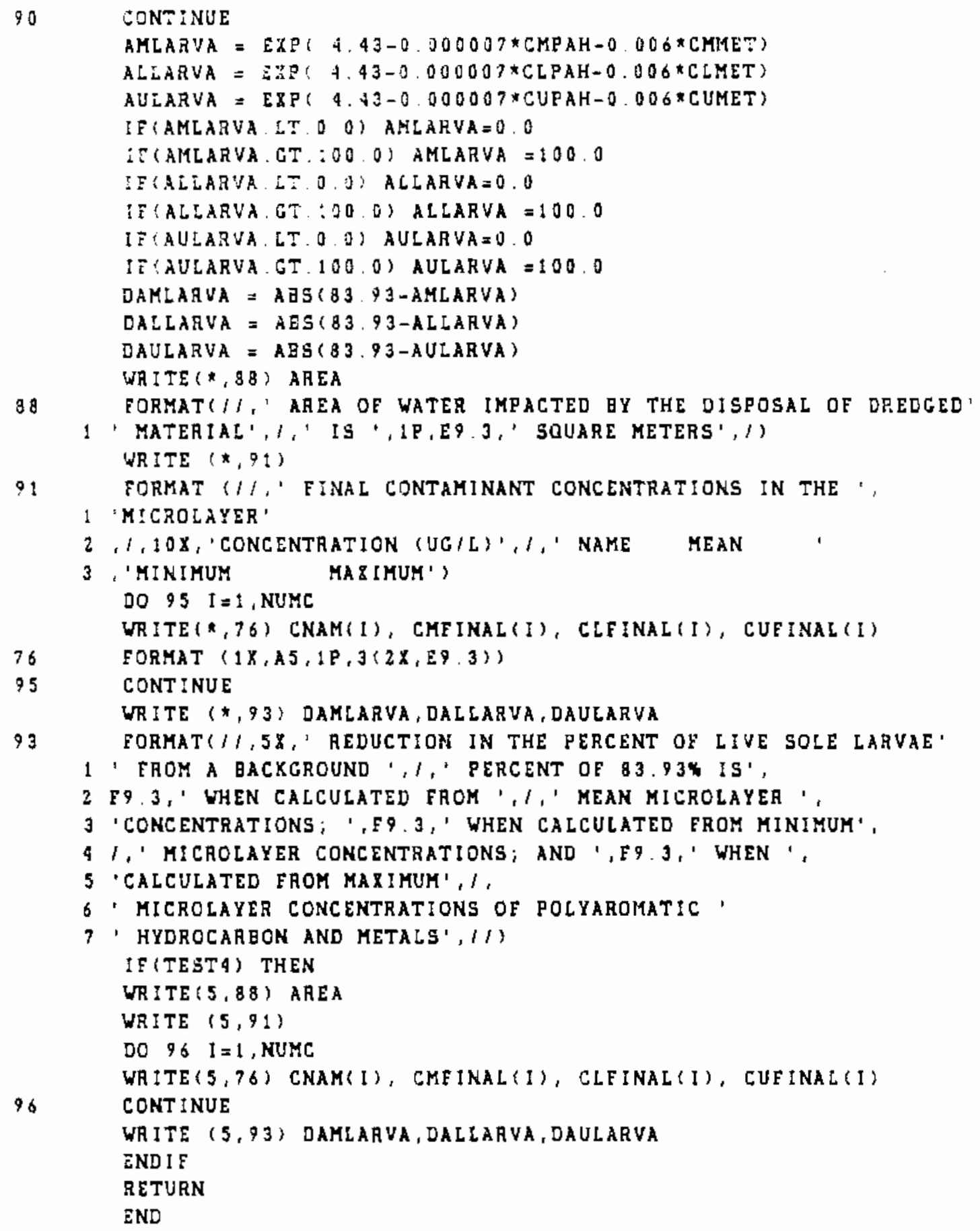




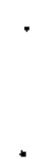




\section{APPENDIX C}

SAMPLE DREDGE DISPOSAL SCENARIOS 


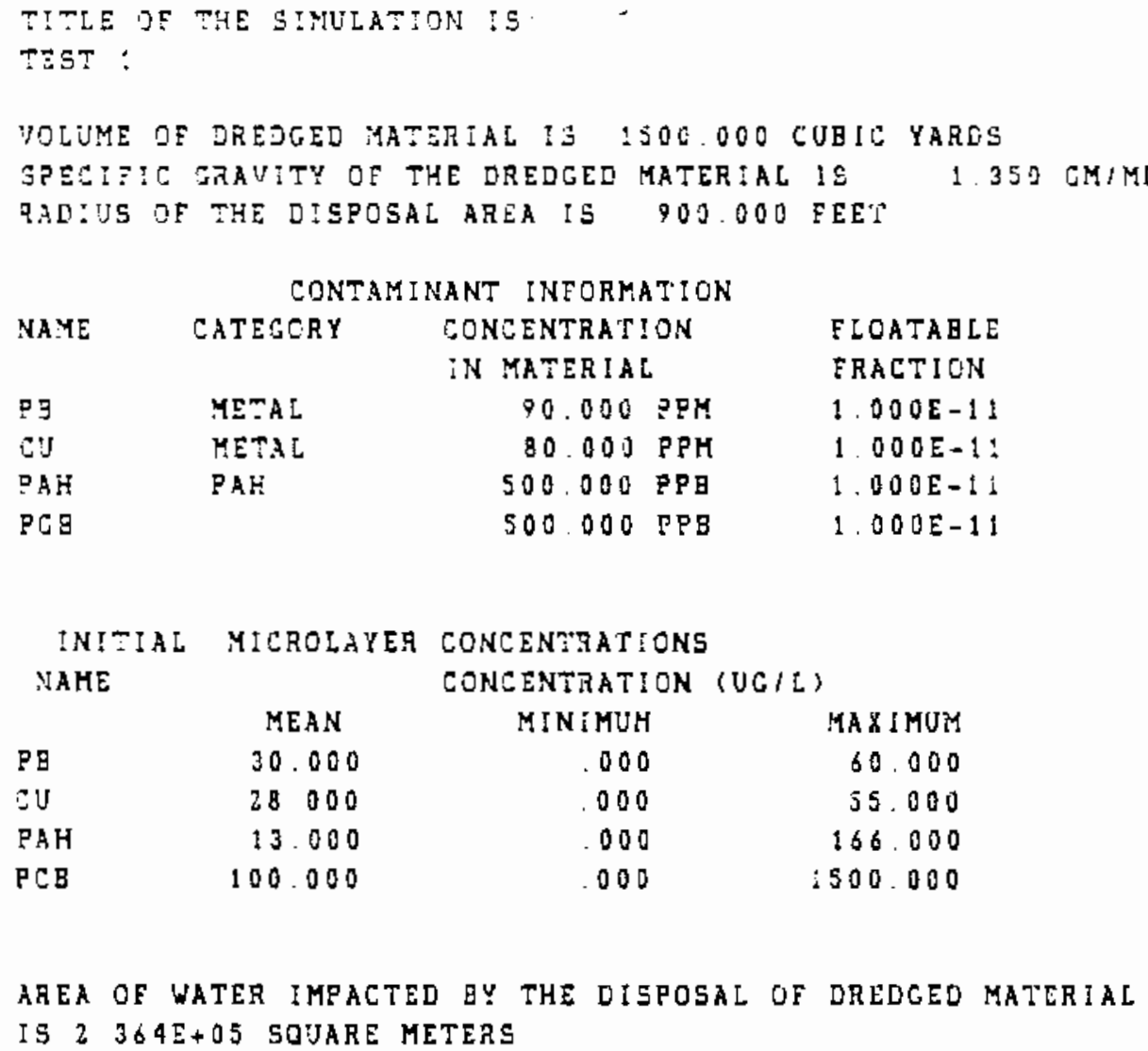




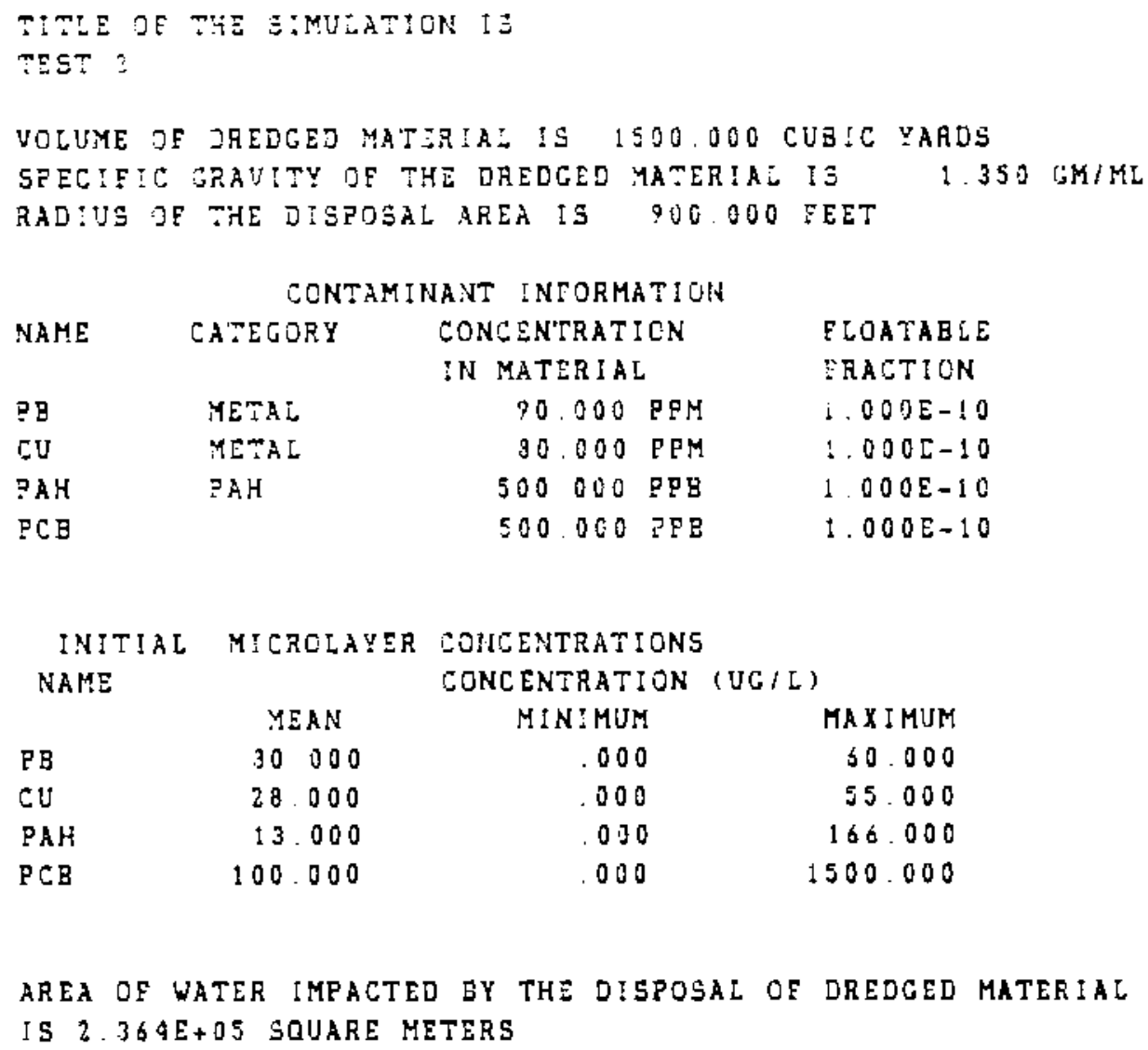

REDUCTION IN THE PERCENT OF LIVE SOLE LARVAE FROM A BACKGROUND PERCENT OF $83.93 \%$ IS 30.541 WHEN CALCULATED FROM MEAN MICROLAYER CONEENTRATIONS; 1.115 WHEN CALCULATED FROM MINIMUM MICKOLAYER CONCENTRATIONS; AND 70.934 WHEN CALCULATED EROM MAKIMUM MICROEAYEA CONCENTRATIONS OF POLYAROMATIC HYDROCAREON ANO METALS 


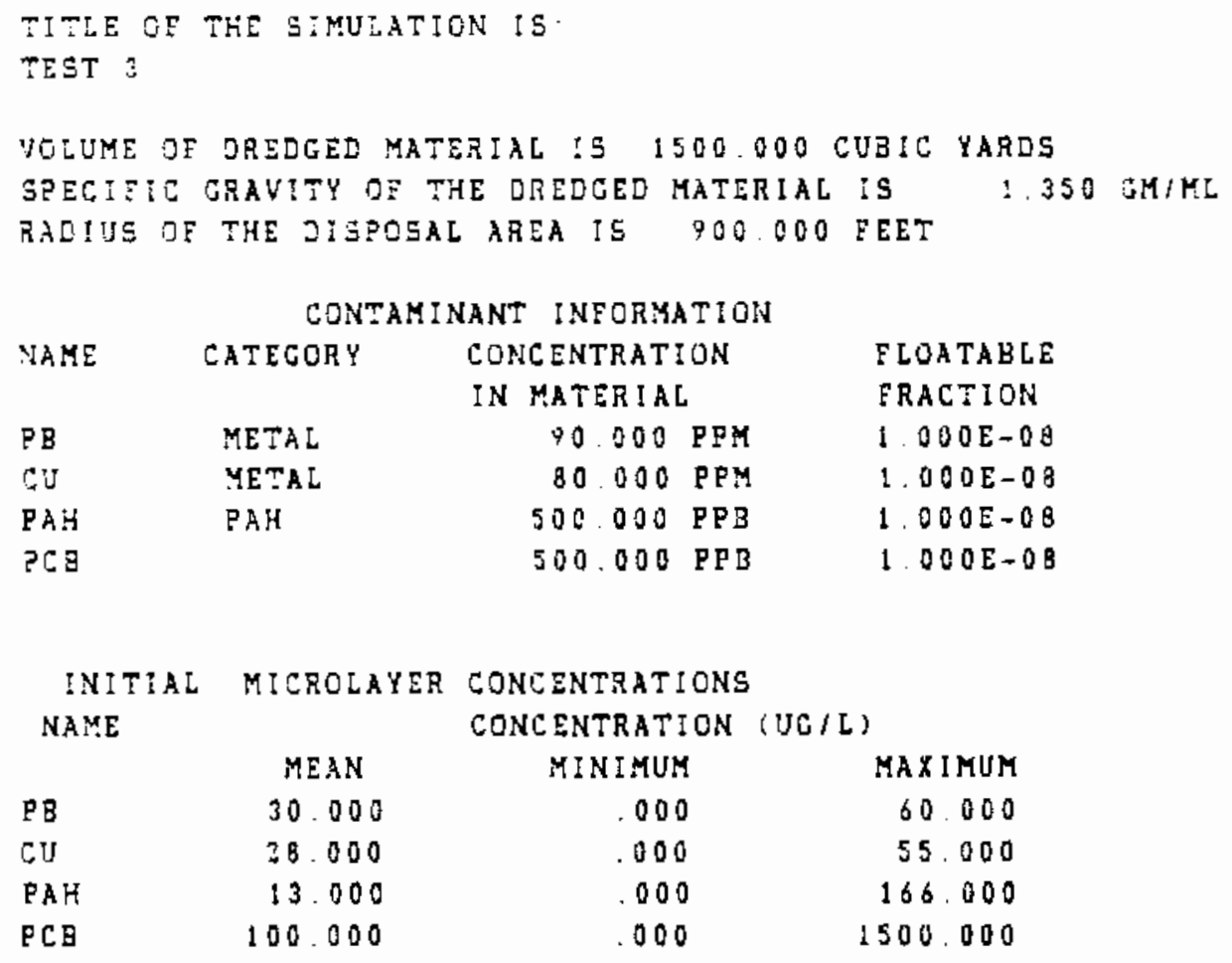




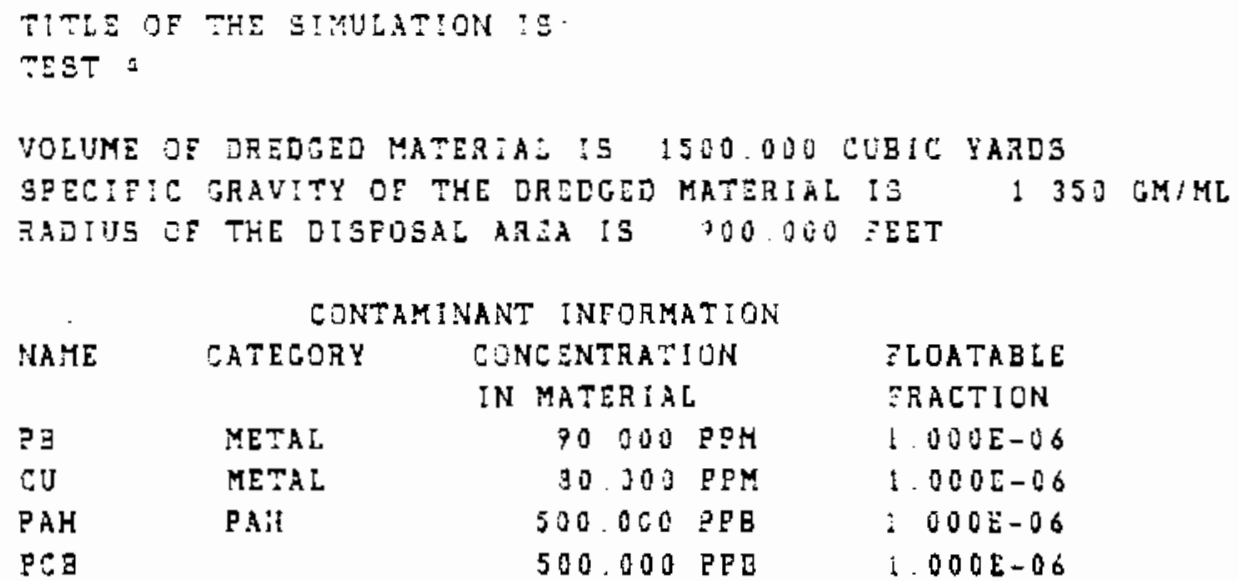

$\begin{array}{lccr}\text { INITIAL } & \text { MICRCIAZZR CONCENTRATIONS } \\ \text { NAME } & \text { CONCENTRATION } & \text { CUC/L: } \\ & \text { MEAN } & \text { MINIMUM } & \text { MAXIMUM } \\ \text { PB } & 30.000 & .000 & 60.000 \\ \text { EU } & 28.000 & .000 & 55.000 \\ \text { PAH } & 13.000 & .000 & 106.000 \\ \text { PEB } & .100 .000 & .000 & 1500.000\end{array}$

AREA OF WATER IMPACTED BY THE DISPOSAL OF DREDGEU MATERIAL IS $2.364 \mathrm{I}+05$ SOUARE METERS

FINAL CONTAMINANT CONCENTRATIONS IN THE MICROLAYER CONCENTRATION (UG/L)

$\begin{array}{lllr}\text { NAME } & \text { MEAN } & \text { MINIMUM } & \text { MAXIMUM } \\ \text { PE } & 1.181 E+04 & 1.178 E+04 & 1.184 E+04 \\ \text { CU } & 1.050 E+04 & 1.047 E+04 & 1.053 E+04 \\ \text { PAH } & 7.844 E+01 & 6.544 E+01 & 2.319 E+02 \\ \text { PCB } & 1.659 E+02 & 6.544 E+01 & 1565 E+03\end{array}$

REDUCTION IN THE PEACENT OF LIVE $30 L E$ LARVAE EROM A BACKCROUND PERCENT OF 83.934 IS 83930 WHEN CALCULATED FROM MEAN MICROLAYER CONCENTRATIONS; 83.930 WHEN CALCULATED FROM HINIMUH MICROLAYER CONCENTRATIONS; AND 93.930 WHEN CALCULATED EROH MAXIMUM MICROLAYER CONCENTRATIONS OE POLYARCMATIC HYOROCARGON AND METALS 


\section{DISTRIBUTION}

No. of

Copies

DFFSITE

2 Keith Phillips

U.S. Army Corps of Engineers

Seattle District

P.0. Box C-3755

Seattle, WA 98124-2255

5 DOE Technical Information Center

Suzanne Bolton Washington Environmental Program Battelle

$2030 \mathrm{M}$ Street Northwest

Washington, D.C. 20036

ONSITE

DOE Richland Operations Office
No. of

Copies

23 Pacific Northwest Laboratory

C. E. Cowan

D. W. Dragnich

R. M. Ecker

C. E. Elderkin

J. M. Hales

J. T. Hardy (5)

P. C. Hays

B. L. Steelman

J. A. Stottlemyre

J. A. Strand

R. E. Wildung

Publishing Coordination (2)

Technical Information (5)

J. J. Sutey 
